\title{
An inquiry into the nature and causes of Climate Wealth of Nations: What temperature finance gravitates towards? Sketching a climate-finance nexus and outlook on climate change-induced finance prospects
}

\author{
Julia M. Puaschunder \\ The New School, Department of Economics, \\ Schwartz Center for Economic Policy Analysis, \\ 6 East $16^{\text {th }}$ Street, $9^{\text {th }}$ floor 89, New York, New York 10003, USA \\ Columbia University, Graduate School of Arts and Sciences, \\ $116^{\text {th }}$ Street Broadway, New York, New York 10027, USA \\ Princeton University \\ George Washington University, \\ CIBER Center for International Business Education and Research, \\ Duquès Hall, George Washington School of Business, \\ 2201 G Street, NW, Suite 450 Washington, DC
}

\begin{abstract}
* Financial support of the American Academic Research Conference on Global Business, Economics, Finance and Social Sciences, Fritz Thyssen Foundation, Research Association for Interdisciplinary Studies, George Washington University, The New School Dean's Office, The New School Department of Economics, The New School Fee Board, The New School for Social Research, The New School Eugene Lang College, University of Vienna and Vernon Arts and Science is gratefully acknowledged. The author declares no conflict of interest. The student thanks Professor Anna Helm and Professor Robert Orttung for most excellent leadership, mentoring and most generous share of expertise during a George Washington University Summer Doctoral Institute 2018. Alexis Gaul and Nevena Yakova's kind interest in my research and benevolent aid was extraordinary. Lucas Humphries, Elena Poliakova, John Ponstingel, Danielle Tomson and Xiangkun Yao's share of insights and collegial care refined the paper in discussions on the ideas underlying and outlined in this paper. All omissions, errors and misunderstandings in this piece are solely the author's.
\end{abstract}

\begin{abstract}
What is the optimal temperature finance gravitates towards? While we have empirical evidence for the optimal cardinal temperature for GDP production and international development links external climate conditions to levels of societal development, no literature exists on climate-induced-finance flows. Research on temperaturedependent financial flows holds invaluable insights in light of climate change. The connection between climate change and finance will be drawn via price mechanisms. Given the extinction potential of crops, industry and service production, price mechanism will be prospected with a hyperbolic tilt towards the end of durability and the closeness to extinction. In contrast to classical and standard approaches in economics to determine prices, the following research thereby takes into account that agents in their behavior can be constrained by shrinking timeframes for production in light of global warming. The contemporary attention to global warming and climate shocks is thereby assumed to affect the price expectations and hence actual market prices of commodities. Paying attention to supply and demand side perspectives,
\end{abstract}


inflated prices surrounding scarcity will be first modelled and then back-tested on data about prices in commodities of food and beverages. Future wealth of nations will be introduced by the concept of climate flexibility defined as the range of temperature variation of a country. So far, a broad spectrum of climate zones has not been defined as asset but climate change will require territories being more flexible in terms of changing economic production. The more climate variation a nation state possesses, this paper argues, the more degrees of freedom a country has in terms of GDP production capabilities in a differing climate. These preliminary insights aid in answering what financial patterns can we expect given predictions the earth will become hotter. Already now this paper presents human capital flows and financial market inflows into areas that are winning economically from a warming globe. The degree of climate flexibility is found to be related to human migration inflow.

Key words: Agriculture sector, Business gains, Cardinal temperature, Climate change, Competitive advantage, Corporate benefits, Economic advantage, Finance industry, Finance prospects, GDP, Global warming, Gross Domestic Product, Industry sector, Service sector.

\section{INTRODUCTION}

Climate change accounts for one of the most debated international concerns. Never before in the history of humankind, the earth has been warming consistently in an unprecedentedly fast pace as outlined by graph 1 based on United States National Aeronautics and Space Administration (NASA) data on the world surface temperature from 1880 until 2017.1

Graph 1: World surface temperature anomalies 1880-2017 derived from NASA temperature measurement

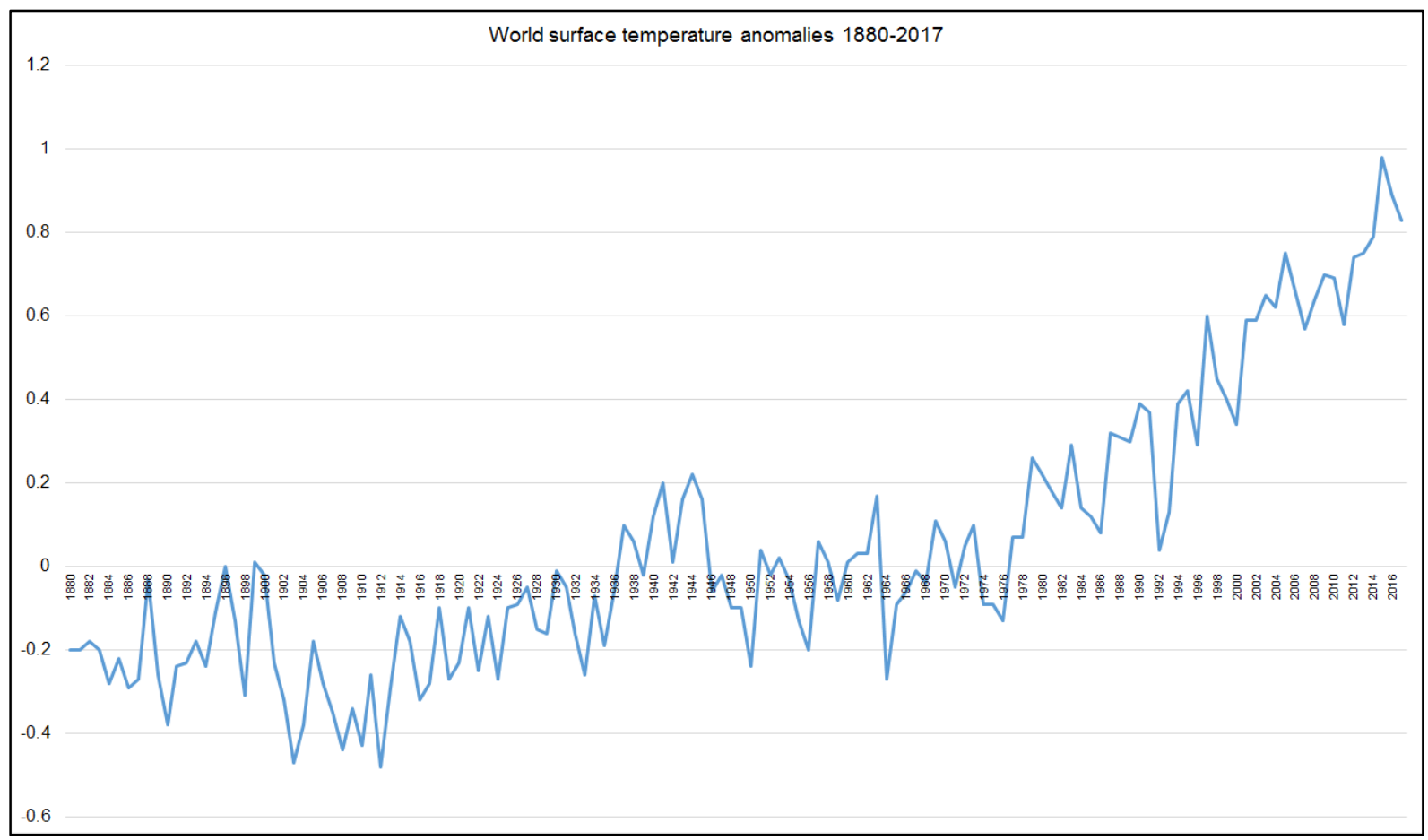

Global warming also appears to be the most lasting external shock event coming down on society ever. The manifold impacts of a hotter temperature are described to be irreversible and widespreadly touching on humankind and natural habitat alike (Environmental Defense Fund, 2018). Climate instability and weather extremes are attributed as one of the most pressing emergent risks imposing dangers onto contemporary humankind (Centeno, Creager, 
Elga, Felton, Katz, Massey \& Shapiro, 2012; Centeno \& Tham, 2012). Climate stabilization accounts for one of the most contested public policy domains as what is at stake is novel, unprecedented and will shape the living conditions of all generations on earth to come (Puaschunder, 2017c, forthcoming b, c; Stiglitz, 1998). The impacts of climate change are believed to influence our daily lives already and the toll climate change takes on us and future world inhabitants is expected to increase exponentially with time (Environmental Defense Fund, 2018). Climate mitigation and adaptation therefore shape markets now and even more so in the future to come.

Money makes the world go round. Around the world, finance is the ultimate means of exchange and a necessary condition to sustain a pleasant living. Access to finance is directly related to freedom. Like no other good, financial assets are linked to social status throughout societal orders of world populations. Finance is the ultimate hammer to nail economies. Financial reserves are storages of economic power and policy leverage. While methods and means have changed, finance is - to this day - the longest serving stabilizer of prosperous societies. Within markets, financial assets move the allocation of goods and services. Finance therefore determines the shape, nature and form of any living community. It is a necessary motivator within economies and a psychological safety coverage for universal risk management. No society exists that does not use any form of finance. Any regime that tried to establish and order society without attention to finance collapsed.

Given the impetus and importance of climate change and finance around the globe and over time, surprisingly striking is that no information exists how climate change will impact finance. While there is research on how finance can be used to curb climate change and orchestrate global warming mitigation and adaptation around the world (Greiner \& Semmler, 2008; Marron \& Morris, 2016; The World Bank, 2015); we hardly know anything about the reverse effect of climate change on financial flows and outcomes. How will a hotter temperature change the finance world? What financial flows will arise in light of climate change gains and losses being distributed unequally around the globe? And lastly, how does climate determine the future wealth of nations?

These are the questions this paper seeks to answer. The paper is structured as follows: The theoretical part tries to connect the worlds of finance and temperature through price mechanisms with attention to supply and demand side perspectives. The impact of a warming earth on financial markets will be prospected (Part 2). A temperature-finance nexus will be introduced (Part 3). A macro-economic finance prospectus on a warming earth will be presented as results (Part 4) containing results on climate change induced market flows (Parts 4.1 and 4.2), climate flexibility (Parts 4.3 and 4.4) as well as climate change expectations driving commodity bubbles (Parts 4.5 and 4.6). A discussion of the findings (Part 5) will lead to final conclusions and a future research endeavors description (Part 6).

\section{Climate change}

\section{THEORETICAL BACKGROUND}

Never before in the history of humankind have environmental concerns in the wake of economic growth heralded governance predicaments as we face today (Nordhaus, 1994). Climate change presents societal, international and intergenerational fairness as challenge for modern economies and contemporary democracies (Bürgenmeier, 1994). In today's climate change mitigation and adaptation efforts, high and low income households, developed and underdeveloped countries and overlapping generations are affected differently. Based on insights from the current endeavor to finance the post-COP21 Paris agreement action 
plan, the Mapping Climate Justice Project proposes a 3-dimensional climate justice approach in order to find a universally fair climate strategy (Puaschunder, forthcoming $a, b$ ).

Mapping Climate Justice elucidates international climate regimes around the world based on geographic, technological, socio-economic and political factors. An interactive graphic solution highlighting different countries' climate stability efforts targets at finding ways to share the benefits and burdens of climate change equally within society, between countries and over time. $^{2}$ Comparing international climate mitigation and adaptation as well as unraveling complex interdependencies is aimed at helping to protect vulnerable communities from variegated climate change risks while opening ways for all to enjoy the upsides of a warming earth.

Climate justice accounts for the most challenging global governance goal. In the current postCOP21 Paris agreement climate change mitigation and adaptation efforts, the financialization of the ambitious goals has leveraged into a blatant demand. In the weighting of the burden of global warming, the benefits of a warming earth have been neglected since recently.

Following the introduction of the gains from climate change (Puaschunder, 2017a, d), the Climate Justice in the 21st Century endeavor proposes a model to distribute the benefits of a warming earth in a fair way based on which countries are losing and which countries are winning from a warming earth until the year 2100. A macroeconomic cost-benefit analysis thereby aids to find the optimum solution on how to distribute climate change benefits and burden within society and over time.

When unidimensionally focusing on estimated GDP growth given a warmer temperature, over all calculated models assuming linear, prospect or hyperbolic gains and losses, the world will be gaining more than losing from a warming earth until the year 2100. Based on the WL index of 188 countries of the world, less countries $(n=78)$ will gain more from global warming until 2100 than more countries $(\mathrm{n}=111)$ will lose from a warming earth.

Based on the overall WLTT index factored by GDP per inhabitant, global warming benefits are demanded to be redistributed in a fair way to offset climate change loser countries for climate change mitigation and adaptation efforts and in order to instigate a transition into renewable energy (Puaschunder, 2017a, forthcoming b). Restructuring industrial systems needs a diverse, cross-sector approach so green industrial policy frameworks can become a valuable tool for all economies to restructure economies towards better societal outcomes (Altenburg \& Assmann, 2018).

Adding onto contemporary climate fund raising strategies ranging from emissions trading schemes (ETS) and carbon tax policies as well as financing climate justice through bonds as viable mitigation and adaptation strategies; climate justice is introduced to comprise of fairness within a country but also among different nation states and over time in a unique and unprecedented tax-and-bonds climate change gains and losses distribution (Puaschunder, 2017b, forthcoming a; The World Bank, 2015).

Thereby, climate change winning countries should be using taxation to raise revenues to offset the losses incurred by climate change. Climate change losers could raise revenues by issuing 
bonds that have to be paid back by taxing future generations. Regarding taxation, within the winning countries, foremost the gaining GDP sectors should be taxed.

Climate justice within a country should also pay tribute to the fact that low- and high income households share the same burden proportional to their dispensable income, for instance enabled through a progressive carbon taxation. Those who caused climate change could be regulated to bear a higher cost through carbon tax in combination with retroactive billing through inheritance tax of the corporate sector that comes into play when a board member changes or there is a merger and acquisition or a hostile take-over. A such corporate inheritance tax could reap benefits from past wealth accumulation that has potentially exacerbated global warming (Rosenlund Soysal, 2018).

This paper builds on the established climate change winning and losing prospects but adds a novel perspective on climate flexibility as the range of different temperatures a country can offer to produce in. Climate flexibility will be captured around the globe and production ranges also analyzed based on flexibility of agricultural crops. Lastly, a climate-finance nexus will be introduced based on expectations of scarcity driving up prices and inflating value of goods that may become scarce in a global warming scenario. Lastly, this theoretical model will be backtested on actual commodity market prices.

Deriving respective policy recommendations for the wider climate change community in the discussion of the results is aimed at ensuring to share the burden but also the benefits of climate change within society in an economically efficient, legally equitable and practically feasible way.

\section{Climate change gains}

The implementation of climate stability accounts for the most challenging contemporary global governance predicament that seems to pit world countries but also today's generation against future world inhabitants. In a trade-off of economic growth versus sustainability, a broadbased international coalition could establish climate stability. As a novel angle towards climate justice, the attention to global warming gains and losses being distributed unequally around the globe (Puaschunder, 2017b) allows to propose to search for a well-balanced climate mitigation and adaptation public policy mix guided by micro- and macroeconomic analysis results.

Based on the medium temperature of countries around the world and the optimum temperature for Gross Domestic Product (GDP) production, the world can be divided into climate change gaining and losing territories until the year 2100. Graph 2 holds those countries that have the most time ahead until optimum temperature for GDP production in green and those that are around peak condition in yellow (Puaschunder, forthcoming b). 


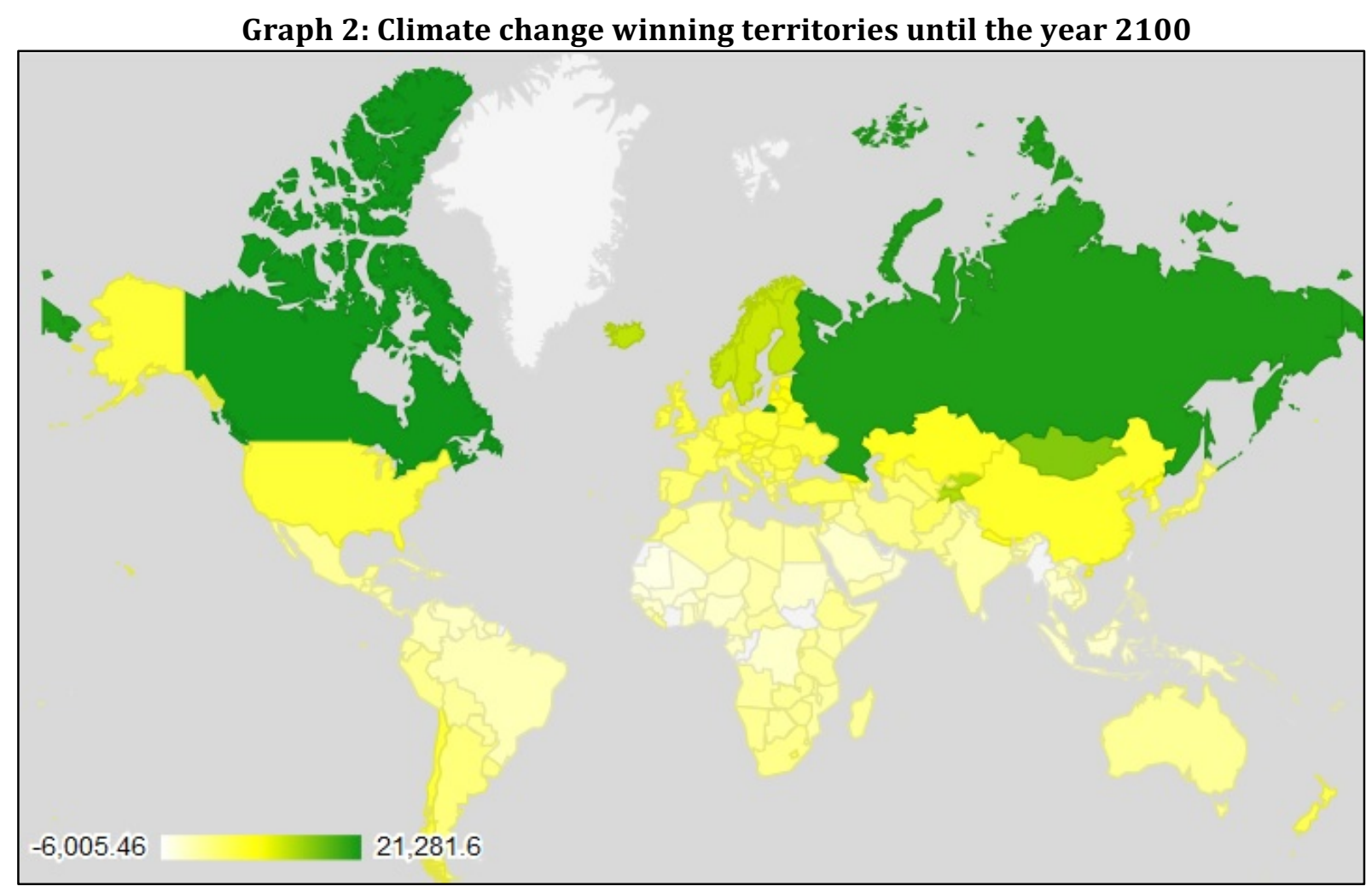

The climate change winning territories are also outlined in Table 1 ranked by country name.

Table 1: Climate change winning territories by country ranked

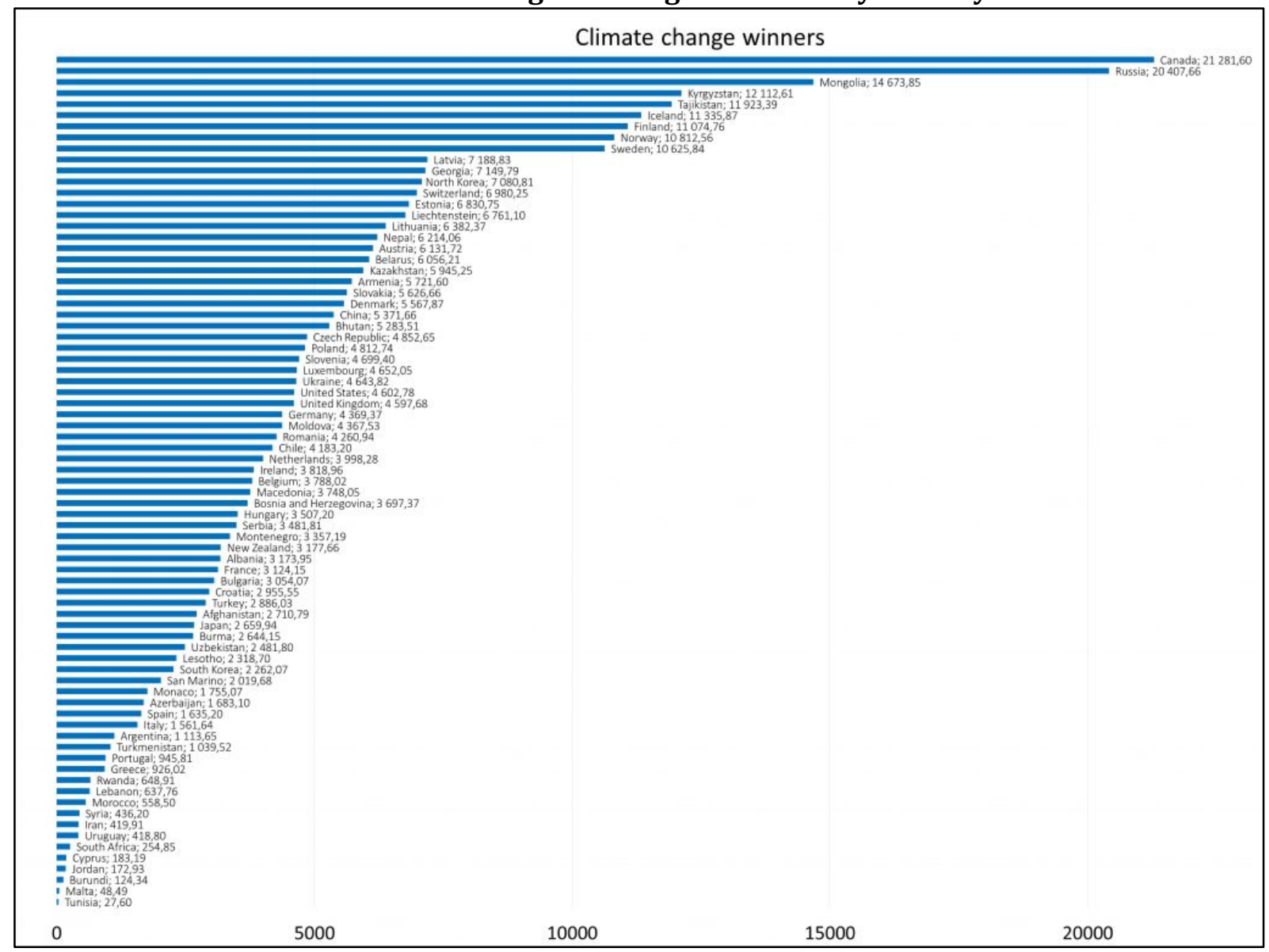


Having found that there are gains from a warming earth demands to transfer benefits into areas of the world that will be primarily losing from climate change. Having shed light on the gains of a warming earth allows for the redistribution of climate change benefits to those areas of the world that will be losing from a warming earth. In the implementation, a climate change bonds but also taxation strategies are recommended. In order to avoid governmental expenditure on climate change hindering economic growth (Barro, 1990); the climate transfers should be enacted through bonds and taxes. The 'Climate in the 21st Century' idea takes these insights into account in order to offer a new way of funding climate change mitigation and adaptation policies but also the transition to renewable energy through broad-based climate stability bonds-and-taxation mix that also involve future generations (Puaschunder, forthcoming b; World Bank, 2015).

First Jeffrey Sachs (2014) proposed an intergenerational burden sharing idea by presenting a 3-model climate change burden sharing through fiscal policy with bond issuing in order to reflect the implementation regarding contemporary finance and growth models with respect for maximizing utility of the model. In an overlapping-generations type model, future research should elucidate climate change abatement and mitigation policies to lead to a fairer solution across generations. The current generation mitigates climate change and provides infrastructure against climate risk financed through climate bonds to be paid by future generations. Since for future generations the currently created externalities from economic activities - the effects of $\mathrm{C02}$ emissions - are removed, this entails that the current generations remain financially as well off as without mitigation while improving environmental well-being of future generations. As Sachs (2014) shows, this intergenerational tax-and-transfer policy turns climate change mitigation and adaptation policy into a Pareto improving strategy. Shifting the costs for climate abatement to the recipients of the benefits of climate stability appears as novel, feasible and easily-implementable solution to nudge many overlapping generations towards future-oriented loss aversion in the sustainability domain (Puaschunder, 2016).

One of the most prominent forms to create revenues for public long-term investment causes are taxes. Taxation is codified in all major societies and a hallmark of democracy (Puaschunder, 2015). Aimed at redistributing assets to provide public goods and ensure societal harmony, taxation improves societal welfare and fairness notions within society. Tax compliance is a universal phenomenon based on cooperation in the wish for improving the social compound. Taxpayers voluntarily decide to what extent to pay or avoid tax that limit the personal freedom (Puaschunder, 2015). In a social dilemma, individual interests are in conflict with collective goals. From a myopic economic perspective, the optimal strategy of rational individuals would be to not cooperate and thus evade tax. Short-term the single civilian tax contribution does not make a significant difference in the overall maintenance of public goods - if only a few taxpayers evade taxes, public goods will not disappear or be reduced. But if a considerable number of taxpayers do not contribute to tax over time, common goods are not guaranteed and ultimately everyone will suffer from suboptimal societal conditions (Dawes, 1980; Stroebe \& Frey, 1982; Puaschunder, 2015). Contemporary economic research has focused on costs and risks of tax evasion (Tyler \& De Cremer, 2006). Coercive means - such as audits and fines - were found to crowd out tax morale and ultimately result in greater noncompliance as people feel controlled and not being trusted (Cialdini, 1996; Feld \& Frey, 2002; Frey, 1992; Hasseldine, 1998). In the last decade, researchers have started to recognize the importance of incorporating morals and social dynamics in economic theory on tax behavior (Andreoni, Erard \& Feinstein, 1998). When analyzing tax behavior, recently behavioral economics insights have drawn attention to social influences (Puaschunder, 2015). 
Puaschunder, J. M. (2019). An inquiry into the nature and causes of Climate Wealth of Nations: What temperature finance gravitates towards? Sketching a climate-finance nexus and outlook on climate change-induced finance prospects. Archives of Business Research, 7(3), $183-217$.

Behavioral economists widen the lens of incorporating sociological and socio-psychological notions of fairness stemming from social comparisons regarding tax burdens that could be positive drivers of tax compliance to overcome the 'burden of taxes' and associations of losses. The cases of voluntary, self-chosen tax ethics and situational influences on social tax compliance norms have just recently been covered by behavioral approaches towards public administration. In general, social comparisons determine social norms that define internalized standards how to behave. Yet internalized social norms are based on comparisons with others that may determine tax morale (Frey, 1997; Mumford, 2001; Schmölders, 1960). Social norms elicit concurring behavior when taxpayers identify with the goals of a group but also if they feel being treated in a fair manner by that group. Social fairness considerations in a tax reference group may further taxpayer compliance. Fairness is believed to decrease egoistic utility maximization leveraging trust and reciprocity as interesting social norms building factors (Kirchler, 2007). Social perceptions of fairness as underlying social norms are therefore potential tax ethics nudges. But psychological facets of fairness for the formation of social norms have been left out. If taxpayers believe that non-compliance is a widespread and socially-accepted, then it is more likely that they will not comply as well. Non-compliance may stem from the notion of unfairness in how the tax burden is weighted heavier on some parts of society.

The respective bonds-and-tax climate stability financing strategy therefore proposes to bear the burden of climate in a right, just and fair way around the globe. In the climate change winner countries, taxation should become the main driver over financing climate stability strategies. Foremost, the industries winning from a warming climate should be taxed. The Winner-Loser-index is based on the cardinal temperatures for all GDP contributing sectors. Based on the cardinal temperatures for the three GDP components agriculture, industry and service, the taxation should be enacted for those sectors having most time ahead. The rational is that these sectors will be gaining the most from a warming earth and will therefore be flourishing.

The taxation models should aid to share the burden of climate change within society in a fair way. Regarding concrete climate taxation strategies, a carbon tax on top of the existing tax system should be used to reduce the burden of climate change and encourage economic growth through subsidies (Chancel \& Piketty, 2015). Within a country, high and low income households should face the same burden of climate stabilization adjusted for their disposable income. First, climate justice within a country should pay tribute to the fact that low- and high income households share the same burden proportional to their dispensable income, for instance enabled through a progressive carbon taxation. Those who caused climate change could be regulated to bear a higher cost through carbon tax in combination with retroactive billing through inheritance tax. But also developed and underdeveloped countries as well as various overlapping generations are affected differently. Besides progressive taxation schemes to imbue a sense of fairness in climate change burden sharing, inheritance taxation is also a flexible means to reap past wealth accumulation, which potentially caused environmental damage. The burden of climate change mitigation and adaptation could also be allocated in a fair way within society through contemporary corporate inheritance tax in order to reap benefits of past wealth accumulation. But in order to determine a fair corporate inheritance tax grantors and beneficiaries, one needs information on what countries and what sectors of the economy have a rising or declining economic prospect in light of climate change.

In addition, finding the optimum balance between consumption tax adjusted for disposable income through a progressive tax scheme will aid to unravel drivers of tax compliance in the 
sustainability domain. If climate taxation is perceived as fair and just allocation of the climate burden, this could convince tax payers to pay one's share. A novel 'service-and-client' atmosphere could promote taxpayers as cooperative citizens who are willing to comply if they feel their share as fair contribution to the environment. Taxpayers as cooperative citizens would then be willing to comply voluntarily following the greater goal to promote taxpayer collaboration and enhance tax morale in the environmental domain. International comparisons of tax behavior also reveal tax norms being related to different stages of institutional development of the government, which is an essential consideration in sharing the climate change burden in a fair manner between countries. A completely novel approach is to shed light on the benefits of a warming earth in order to derive fair climate gains distribution strategies around the world (Puaschunder, 2017e). This paper will add on the basic climate change winning and losing prospects model (Puaschunder, forthcoming b) with specific market outlooks given a global warming trend based on novel concepts such as climate flexibility and climate change induced financial and human migration flows as well as market price expectations around scarcity (Cifarelli \& Paesani, 2018; Dukhanina, Leveque \& Massol, 2018; Ekholm, 2018; Elgouacem \& Legrand, 2018; Puaschunder, 2018 a).

\section{Climate change losses}

Based on the medium temperature of countries around the world and the optimum temperature for Gross Domestic Product (GDP) production, the world can be divided into climate change gaining and losing territories until the year 2100. Graph 3 holds those countries that have passed the peak temperature for GDP production in red (Puaschunder, forthcoming $b$ ).

\section{Graph 3: Climate change losing territories until the year 2100}

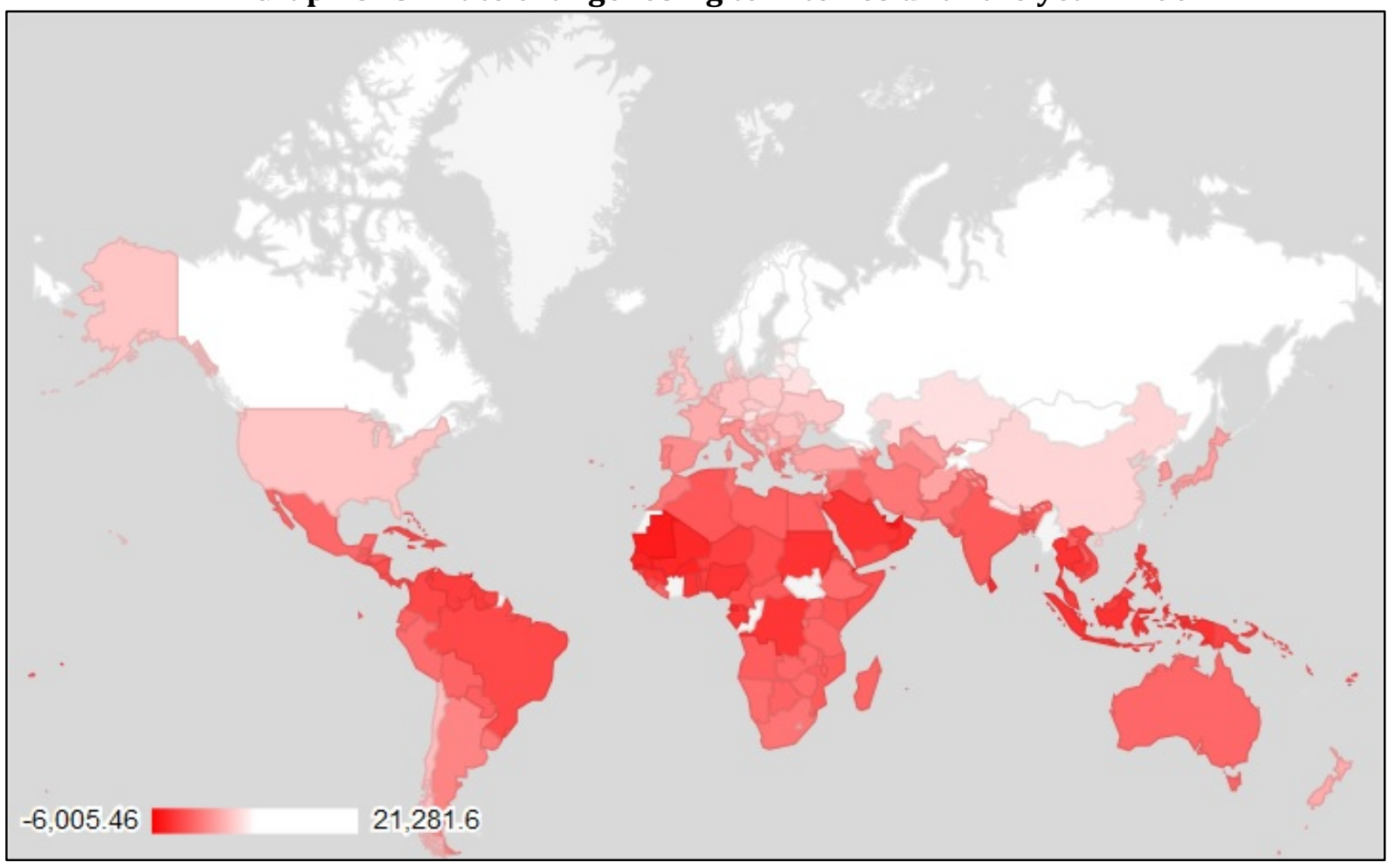

The climate change losing territories are also outlined in Table 2 ranked by country name. 
Table 2: Climate change losing territories by country ranked

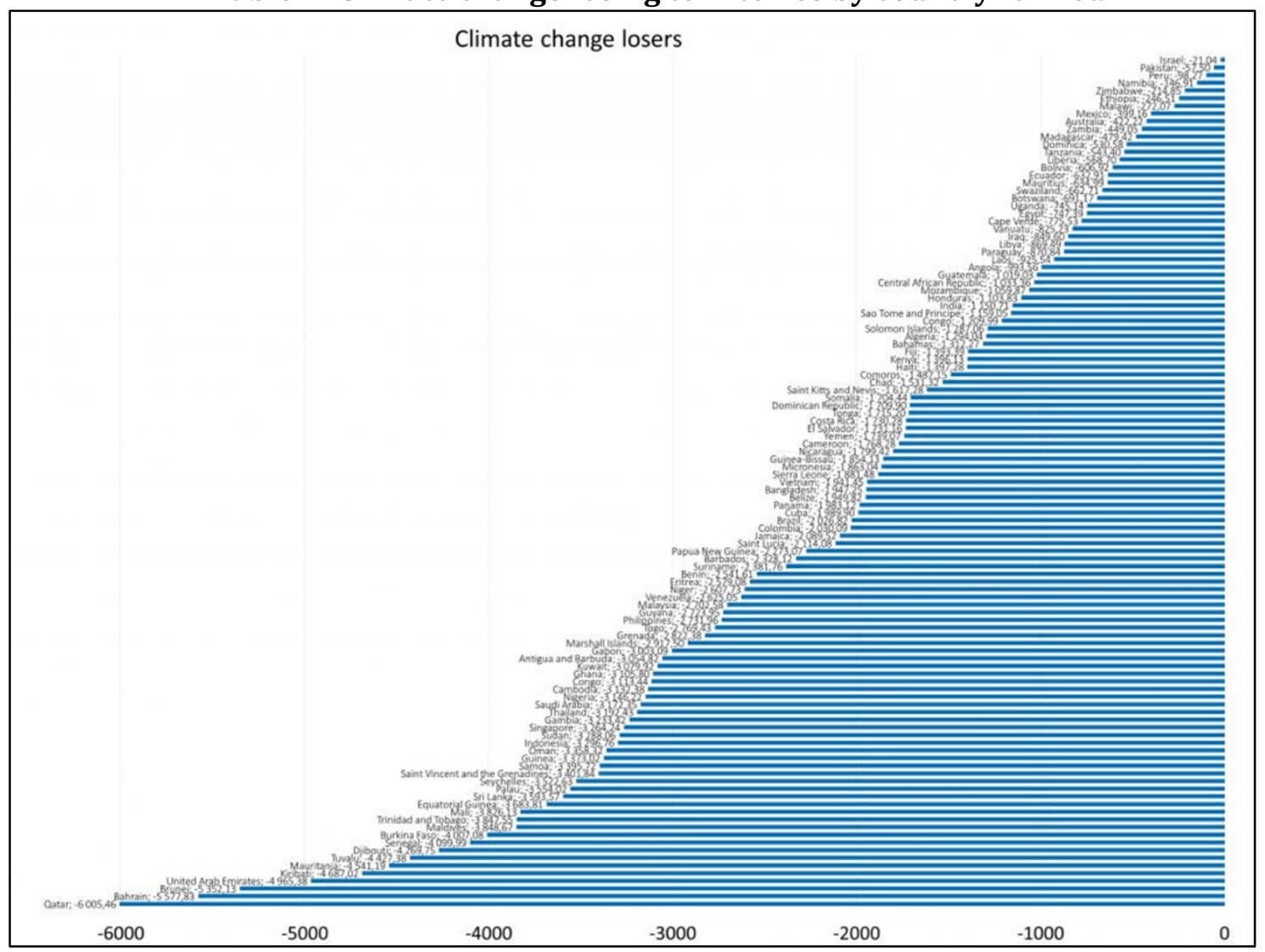

Introducing financing climate change mitigation through bonds to be paid back by future generations through taxation is a means to raise funds for offsetting the losses of global warming. As a novel way to amend individual saving preferences in favor of future generations, Sachs (2014) proposes to mitigate climate change by debt to be repaid by tax revenues on labor income in the future. In a 2-period model, one generation works in period 1 and retires in period 2. Part of the disposable wage income is saved for consumption in the second period. CO2 emission mitigation imposes immediate costs onto current generations and reduces wages. Greenhouse gas concentrations in period 2 are determined by the emissions in period 1. Wages of the young in the second period are reduced by climate change dependent on greenhouse gas levels. Disposable labor income of the young equals market wage net of taxes. Leaving the current generation with unchanged disposable income allocates the burdens of climate change mitigation across generations without the need to trade off one generation's well-being for another's.

While today's young generation is left unharmed, the second period young generation is made better off ecologically. The bonds solution should be pursued in climate change loser countries, in order to offset the costs for climate change in a more intergenerationally harmonious way. Since the majority of GDP contributing factors is losing in climate change loser countries, future generations should be serving as last resort to pay for climate stability. While future generations enjoy a favorable climate and averted environmental lock-ins; the current populace does not face drawbacks on economic growth (Puaschunder, 2017a, b, d). All generations are better off with mitigation through climate bonds as compared to the businessas-usual (BAU) non-mitigation scenario (Puaschunder, forthcoming b; Sachs, 2014). 
Governments in loser countries should receive tax transfers in the present from the winning countries. Since here borrowing equals loans or issuing of bonds to be paid back by future generations, the government must pay back debt plus interest payments by raising taxes on later generations. Taxing future generations is justified as for the assumed preferences of future generations to avoid higher costs of climate change long-term damages and environmental irreversible lock-ins. Overall this tax-and-transfer mitigation policy thus appears as a Pareto-improving fair solution across the world and generations. While there seems to be a strategy how to raise funds for the stabilization of the climate, hardly any information exists on how the changing climate may affect the finance world.

\section{Finance industry}

The financial industry provides financial services, which encompasses a broad range of businesses that manage money, including credit unions, commercial and investment banks, credit-card companies, insurances, accountancy consulting, consumer-finance companies, stock brokerages, investment funds, individual managers and some government-sponsored enterprises (Asmundson, 2017).

The financial sector is a category of the economy made up of firms that provide financial services to commercial and retail customers. The term "financial services" became more prevalent in the United States partly as a result of the Gramm-Leach-Bliley Act of the late 1990s, which enabled different types of companies operating in the U.S. financial services industry at that time to merge. Foreign exchange services are provided by banks and specialist foreign exchange brokers around the world including wire transfer and remittances services (World Bank Group Migration and Development Brief, 2016). Insurances are additional financial services offered as risk management tool. Financial export is a financial service provided by a domestic firm (regardless of ownership) to a foreign firm or individual. A large portion of this sector generates revenue from mortgages and loans.

Finance is a field that deals with the study of investments and is the science of money management. It includes the dynamics of assets and liabilities over time under conditions of different degrees of uncertainties and risks. Market participants aim to price assets based on their risk level, fundamental value and expected rate of return. Finance is used by individuals (personal finance), by governments (public finance), by businesses (corporate finance) and by a wide variety of other organizations such as schools and non-profit organizations. Finance is one of the most important aspects of business management and includes analysis related to the use and acquisition of funds for the enterprise. Finance can be broken into three subcategories: public finance, corporate finance and personal finance.

Macroeconomic public finance concerns center around the amount of money in an economy; inflation within economies; exchange rate differences between countries; retirement and social security planning, gold reserves as well as estate investments. Central banks are public finance entities, acting as lenders of last resort with influences on monetary and credit conditions in the economy.

Corporate finance deals with the source funding and capital structure of corporations; shareholder wealth maximization; cash flow and capital budgeting; investment management and asset diversification. Commercial finance adds a broad range of financial services such as stock brokerage; portfolio management; risk management strategies; hedge fund management; private equity and asset accumulation goals. The accounting industry is primarily focused on the reporting of historical financial information. Financial risk management strategies encompass risk estimations based on credit and market risk prospects. 
Personal finance is concerned about the investment and accumulation of assets; insurance protection against unforeseen personal events, as well as events in the wider economies; transfer of family wealth across generations; tax planning; management of personal finances; effects of credit on individual financial standing, savings plan or financing for large purchases; and planning a secure financial future in an environment of economic instability.

Banks are financial intermediaries that aggregate the activities of many borrowers and lenders. A bank accepts deposits from lenders, on which it pays interest. The bank then lends these deposits to borrowers. Banks allow borrowers and lenders, of different sizes, to coordinate their activity. The owners of both bonds (either government bonds or corporate bonds) and stock (whether its preferred stock or common stock), may be institutional investors - financial institutions such as investment banks and pension funds or private individuals, called private investors or retail investors.

Financial economics is the branch of economics studying the interrelation of financial variables, such as prices, interest rates and shares. Financial economics concentrates on influences of real economic variables on financial ones. A country's economy is a social institution that organizes a society's production, distribution, and consumption of goods and services, all of which must be financed.

Given the impetus and importance of climate change and finance around the globe and over time, surprisingly striking is that no information exists how climate change will impact finance. How will a hotter temperature change the finance world? What financial flows will arise in light of climate change gains and losses being distributed unequally around the globe? And lastly, how will global warming determine the future wealth of nations?

This paper tries to introduce three market mechanisms of climate change on finance based on (1) climate flexibility as the range of different temperatures offered by a nation state and agricultural production commodities as well as (2) climate change related finance, human and innovation prospects and (3) inflated prices in the prospect of rising scarcity induced by global warming.

\section{Price mechanisms}

The financial industry is centered around prices. Price determine the value of a good based on supply and demand. Classical price theory started with Adam Smith, who described as first that free interaction creates an orderly pattern guided by the invisible hand. Competition creates order out of activities in market, where consumer and producer meet over determining the price of goods. Profit rates gravitate around natural prices. Market prices are invisible centers of gravity and profit rates equalize due to the mobility of captial. High profit rates attract capital that brings the market prices down. Low profit rates will slow down supply in the movements of market prices. Prices move around centers of gravity among each other. The natural course is that actual market prices are above or below the natural price. The central price is the price to which all prices gravitate continually. According to Smith, the price of production has a natural profit, which is only achieved through gravitation. The natural profit is the profit one deserves added to costs.

Exchange takes place in disorder, in which prices guide through the monetary expression of a commodity's quantitative worth. Market prices gravitate in a turbulent manner around prices of production. Profit is an objective measure subject to constant scrutiny by the firm's managers, the stock market, the banks and the public in general. The uniform price is assumed 
to be supremely responsive to the market demand and supply. According to Kalecki's Theory of Price, the price of individual firms depends on the relative size of firms due to union power of employees, industry prices and average costs and monopoly power that determine the mark-up structure.

According to Adam Smith, the profit motive is the dominant factor in the regulation of economic growth. Actual decisions are always made in terms of current and expected market prices. Expected profitability at the core of any economic activity implies a mode of interaction between aggregate demand and supply. Profit thus regulates both - supply and demand. Profit determines an endogenous natural rate of growth. The interest rate thereby becomes the price of finance. Financial firms exist to make profit, and competition makes the profit rate of the regulating financial capitals gravitate around the general rate of profit.

Price is the quantitative worth of a commodity expressed through the medium of money. Direct prices represent a set of monetary prices that are proportional to labor values. The sum of direct prices equals the sum of market prices. The inclusion of depreciation lowers the dispersion for direct prices and the inclusion of fixed capital lowers the dispersion for prices of production. Price mechanisms around scarcity feature demand-driven bubbles, hence inflated prices (Bai, Koong \& Valenzuela, 2018; Bonato, 2018; Ielpo \& Sevi, 2009; Ji, Liu, Zhao \& Fan, 2018). For instance, during the great stagflation the price of gold rose from $\$ 125$ to $\$ 615$ before to subsiding to $\$ 375$ by 1982 . During the German hyperinflation of the 1920 s, prices were actually in gold even through the money which changed hands was fiat paper. Profit drives capitalism. If profit fails, the shock lets capital begin to atrophy.

In general, there is a complexity of the calculation of prices via an input-output system that prevents a simple description of the relation of a commodity's prices to any other single parameter (Bienenfeld, 2002; Sraffa, 1960). Divergences in price expectations are mainly captured to stem from the organic composition of capital in each industry and relative capital intensity in layers of goods and the vertically integrated value composition of capital as an intricate network of relations between rate of profit and prices in the whole economic system (Bienenfeld, 2002). But how temperature may change the perception of goods and scarcity in light of climate changing patterns of production may influence pricing mechanism, we do not know (Ganepola, Garrett \& Cho, 2018; Ordu-Akkaya \& Soytas, 2018). The described climate change winning and losing territory aspects and prevailing demands for a restructuring of gains into the losing areas are expected to create market distortions, which have not been described sufficiently. In determining price mechanisms, information how climate influences prices is missing. Thereby supply and demand side perspectives should be considered. Politics may also play a crucial role (Orttung, 2010a, b, 2014, 2015, 2016; Orttung \& Overland, 2011a, b; Perovic, Orttung \& Wenger, 2009).

Prices appear to be dependent on the prices of production, which depend on fixed capital, turnover, wages, return on capital, capacity utilization and capital stock (Cockshott \& Cottrell, 1994; Leontief, 1997). Ricardo (1817/1951) argued that changes in relative prices are dominated by changes in relative vertically integrated labor coefficients. Marx (1867/1995) outlined that relative prices move directly with changes in vertically integrated labor coefficients and inversely with changes in relative vertically integrated labor productivity, which even holds for prices of production (Chilcote, 1997). Evaluating the sensitivity of different prices of production estimators to temperature changes can provide insights for market estimations about depreciation, fixed capital, turnover, and capacity utilization into the estimation of prices of production. 
All firms have market prices. Firms constanty try to reduce prices in order to get an edge over competitors. Competition is driven by competitors trying to sell cheaply to drive out competitors based on technological change lowering costs and cheapening commodities. Competition tends to equalized wage rates and profit rates, around which market prices tend to gravitate, but remain different from natural prices of production.

Market prices may gravitate around feasibility of production rather than direct prices. Deviations of market prices from prices of production mostly reflect imbalances in supply and demand conditions. Expectations about shrinking production possibilities may inflate prices to an irrational exhuberance around scarcity. Competition between industries makes relative prices of individual commodities gravitate around prices of production price reflecting equal profit rates.

John Maynard Keynes and Karl Marx tie prices to periodic recurrence of boom and bust in Capital and the General Theory (Sherman, 1967). According to Keynes, firms do not set prices, competition sets prices. Firms cannot set any level, raise them at certain level or pressure competition. In the classical theory of money, price wages and levels of production determine the long-run growth rate. According to Keynes, prices depend on confidence in the future, whereby a collapse of confidence precipitates capital flight.

In the Marxian tradition, one could argue that the inequality of climate change wins and losses around the globe, opens a climate hegemony in the $21^{\text {st }}$ century. Naturally imposed temperature constraints may implicitly determine prices. Scarcity around temperature flexibility may create market distortions and surreal demand inflating prices to climateinduced bubbles (Moore, 2009). With increasing scarcity, prices are driven sky high which provides high returns to shareholders. In a world where some places may run out of production capabilities due to temperature, climate spectra may become the new center of gravity towards production naturally gravitates.

According to Sraffa (1960), the price of commodities is a joint result of the price of the commodity itself, the costs of the commodity production as responding to changes in the prices of those commodities, which enter into its production. A firm's competitive edge may be determined by climate flexibility, which may derive from natural propensities of national territories and climate areas span of corporations in the age of global warming.

In today's world, temperature-related production flexibility may regulate the market price. Firms with leeway to produce in different climatorial zones may thereby become active pricesetters. Fluctuations in aggregate demand cause the economy to come to short run equilibrium above or below full employment. Shrinking temperature windows for production of commodities may trigger expectations that determine prices. Expectations are a thought or a belief about anticipated gains or losses (Soros, 2003). Expectations are thereby anticipations of an expected future value in an uncertain world (Soros, 2009, 2013). Expectations are a central part of value calculations in economics. The subjective expected utility is derived from the value of an outcome and the probability that it will occur. Expectations elicitation is used in many domains, including health, wealth, survival and educational outcomes, but may be most prominent in financial realms. While we know that consumers with more optimistic stock market expectations tend to more likely hold riskier assets and acquire stocks in the near future; we still are in need to explore what information and factors drive financial market expectations in light of a warming globe. 
Expectations play a vital role in economic calculus. Since firms have to produce for the future, any production is based on expectations on future outcomes in Keynes. Expectations are formed in a dynamic process. Anticipations are skewed and dependent on other people. Expectations influence what happens in the process as people do not correctly anticipate what happens. Soros' (2003) financial market theory holds that some people will belief that people will go on forever. They do not know when turn will happen. If a sufficient number of people beliefs that the system is not sustainable, the bubble bursts. One knows that it will happen but not when it will happen. According to Friedman, surprises in markets matter more than expectations. Every deviation besides surprises are temporary. Information on the linguistic correlates of economic ups and downs could help 'bridge between rational behavior and societal collective action' (Soskice, 1978).

To every good and service there is a (1) fundamental value $f$, what a good is actually worth, when considering the direct market price and price of production and (2) expectations $e$. When information in markets builds up expectations, $e>f$, hence expectations start overpromising beyond the fundamental value. People believe a good or service is more worth than its actual fundamental value is. If $e$ gets largely inflated and majorly detached from $f$, first market experts start realizing the unsustainable inflation of a good's or services' expected value. The first market actors start losing faith in the product and service, hence trying to sell it. If the amount of sale bids reaches a certain threshold, by the law of supply and demand, the price will eventually decline and then, if bleeding into a run and more investors to follow, eventually collapse. This is the nature of the collective soul of booms and busts as outline in Graph 4.

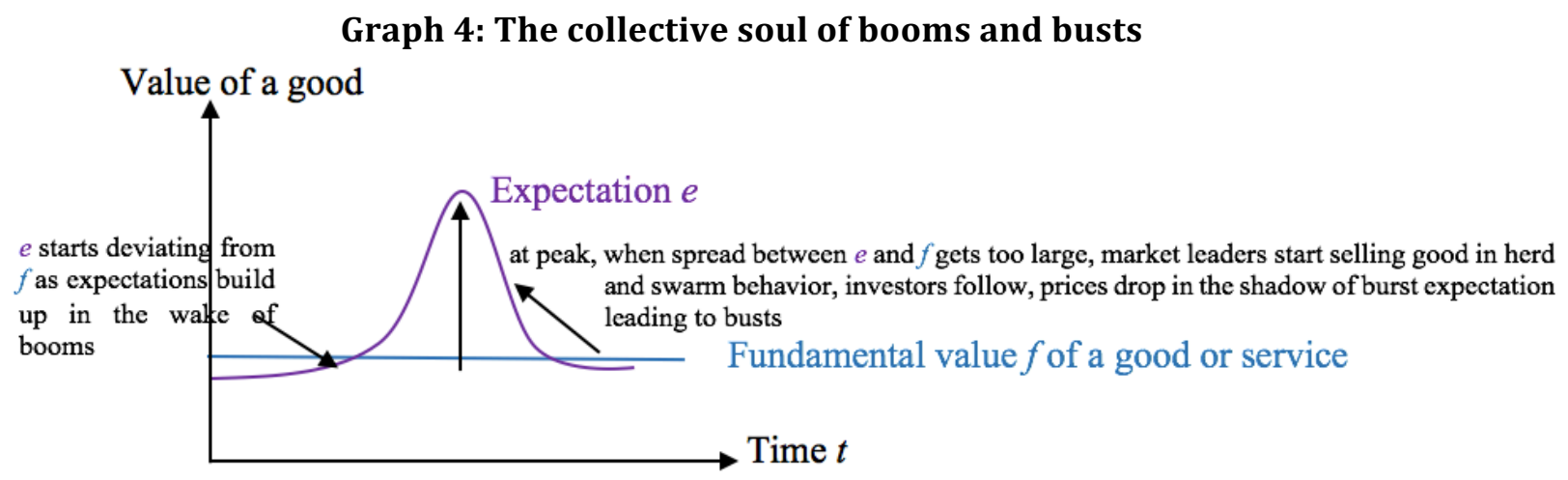

While we have information about the mathematical calculus of the expected value of a discrete random variable being the probability-weighted average of all possible values, mainly estimated as probabilities by frequencies; we lack an understanding of the economic correlates in the wake of socio-psychological phenomena regarding expectations of scarcity and fear of losses surrounding from climate change. To this day we have no sound information how expectations are built up in markets and how the over- or underperformance creates social norms around markets that may trigger herd behavior or inflate swarm phenomena. In general, we can assert the higher a person's expectation and the lower the performance, the higher the frustration and trigger of cessation of activity and quitting behavior - yet what this means for financial market decisions in the eye of a changing climate shrinking our natural prospects of productivity possibilities, we have no concrete information about. Behavioral economics found people to be risk-averse and their loss prospects loom larger than gains, which may influence their inflated willing-to-pay in light of loss prospects surrounding scarcity of goods (Kahneman \& Tversky, 1979). How scarcity prospects reflect on energy prices, is a currently growing research field in finance with applications in the natural gas market and oil sector (Kilian \& Zhou, 2018; Klein, von Mettenheim, Walther \& Wegener, 2018; Kruse \& 
Wegener, 2017; Legnazzi, 2018; Mahadeo, Heinleinb \& Legrenzib, 2018; Markowitz, Grasso \& Jamieson, 2015).

As people develop favorable and unfavorable expectations that guide their choices and behavior on a daily basis, we need to unravel how climate change related expectations are created and how they influence economic market actors' decisions bleeding into the collective soul of booms and busts. In the need for sustainable finance, we therefore need to unravel the impact of expectations regarding a changing climate determine our economic prospects and hence market actions (Schütze, Aleksovski \& Mozetic, 2018; Schweiger \& Stepanov, 2018). Central Banks and market prospects play a crucial role in shaping expectations and correcting overshooting or undershooting in market predictions (Puaschunder, 2018 b).

\section{Research contribution}

The following part will connect the contemporary ground-breaking research on climate change gains with the financial prospects in light of a warming globe. The paper will thereby release unprecedented information on finance prospects given a warming globe and what finance market changes to expect given climate change. Lastly, the paper will provide recommendations for market actors how to adapt to climate change elegantly and reap benefits from a warming globe.

\section{Overall model assumptions}

\section{METHOD}

\section{Study 1: Climate change induced market flows}

Puaschunder's (forthcoming b) model is built on GDP optimal cardinal temperature for production. The GDP pillars of agriculture, industry and service are the foundation of the model. The model divided the world nation states into climate change winning and losing territories (Puaschunder, forthcoming b). This is in accordance with International Monetary Fund (IMF) work of IMF research division. Contemporary International Monetary Fund (IMF) research concludes that in low temperature countries, an increase in temperature boosts economic activity, while in higher temperature countries, an increase in temperature will dampen economic activity (Acevedo, Mrkaic, Novta, Poplawski-Ribeiro, Pugacheva \& Topalova, 2018). The findings of uneven economic effects are robust over the different models and backed by regional cluster analysis and geographic case studies (Burke, Hsiang \& Miguel, 2015; Somanathan, Somanathan, Sudarshan \& Tewari, 2014; Topalova, in speech, 2018). ${ }^{3}$ The IMF model now sophisticates these findings with insights about the effect of temperature on productivity, capital and labor (Topalova, in speech, 2018). ${ }^{4}$

In order to consolidate these findings and derive implications for economic and financial market performance, three market-focused hypotheses will test whether climate change winning and losing territories attract different levels of human capital inflow, finance inflow and internet connectivity.

Overall geographical mobility is expected to increase and thus should be supported, especially when massive shifts of the industry structure result from green industrial policies. This may be the case, for example, when shifting from fossil to renewable energy: Fossil energy plants

\footnotetext{
${ }^{3}$ http://www.economicpolicyresearch.org/events/upcoming-events/the-economic-impacts-of-weather-shocksand-climate-change-how-can-countries-cope

${ }^{4}$ http://www.economicpolicyresearch.org/events/upcoming-events/the-economic-impacts-of-weather-shocksand-climate-change-how-can-countries-cope
} 
are usually located next to energy-intensive industries and cities, whereas renewable power plants are located where the respective power resources are abundant. Shifting energy systems will therefore affect spatial distribution and workers are therefore expected to move physically (Esposito, Haider, Semmler \& Samaan, 2018).

Hypothesis $\mathrm{H}_{1.1}$ investigates if countries that economically benefit from climate change feature a significant foreign human capital inflow (Puaschunder, forthcoming b).

Hypothesis $\mathrm{H}_{2.1}$ investigates if countries that economically benefit from climate change feature a significant foreign capital inflow that does not correspond with remittance outflow from the FDI receiving territories into the FDI sponsoring countries (Puaschunder, forthcoming b).

Hypothesis $\mathrm{H}_{3.1}$ investigates if countries that economically benefit from climate change feature a significant higher level of internet connectivity.

\section{Study 2: Climate flexibility}

In a model extension of the original calculation of climate change winners and losers around the world based on GDP prospects (Puaschunder, forthcoming b), Puaschunder (work in progress) focuses on agriculture, industry and service sector representing economic growth factors. Methologically, the optimum cardinal temperatures for specific agriculture products, industry representations and service sector providers was retrieved from literature sources (Puaschunder, work in progress). A future market prospect in light of global temperature rising was then given based on the mean temperature of the world now and as estimated in the year 2100. Prospective market shifts in the GDP compostion but also agricultural products, industry sector representatives and service providers were provided. Underlying to all these future prospects is the idea that GDP production and its manifold components is enabled at best at a certain temperature and therefore specific markets will follow and gravitate towards these temperatures (Puaschunder, work in progress).

In light of global warming, a influx of labor and mobility of corporations is predicted. These insights fortify the idea that the world will become more globalized and location-flexible due to climate change. Those corporations and individuals realizing this and seeking the gains of a warming globe - maybe beyond their own little inhabited territories are prospected to become market winners. The idea of protectionism is doomed to fail in the eye of global warming.

\section{Study 3: Climate change expectations driving commodity bubbles}

Since the turn of the millennium, the United Nations (UN) detected an unprecedented agriculture products commodities bubbles trend especially in countries around the equator belt, which are the worst off regarding climate change due to a natural high base mean temperature (United Nations Report on the World Social Situation, 2011). There also seems to be a recent and unprecedented credit risk and bubble behavior in the corporate energy sector - such as oil-supply shocks and stock prices - that may be related to the demand for a transition to renewable energy (Figuerola-Ferretti \& Cervera, 2018; Kaabia, Dhaoui, Abid \& Guesmi, 2018; Lips, 2018). In the oil energy sector, price spikes have been found around procurement shortages, which are expected to be occurring in all climate-related extinction cases (Roberts, Barbier \& van't Veld, 2018). Research also already pits food versus fuel and finds evidence of a contemporary predicament in nation state's investment allocations in either one resource (Filip, Janda, Kristoufek \& Zilberman, 2018; Trinks, Mulder \& Scholtens, 2017). There is also already evidence for sector competition for energy resources in a carbon constrained hoteling model (Renz, 2018). This may only be a first sign of agricultural products becoming more precious and valuable for economic production given a longer durability in a 
warming climate (Wenger, Orttung \& Perovic, 2009). Energy prices and mitigation policies also impact on Foreign Direct Investment (FDI) locations (Mourougane, Botev \& Dlugosch, 2018; Saussay \& Sato, 2018; The World Economic Forum 2015 Report, 2015; World Investment Report, 2015).

The following financial market model now estimates prices centered around agriculture, industry and service sector transitions. Based on evidence from the energy sector, the relation of a price of a good and time to extinction of a resource is not linear but hyperbolically tilted towards the end before extinction (Roberts et al., 2018). When a resource is about to go extinct, the market value of this resource will in general rise shortly before the good goes away from the market forever. For instance, if we run out of a natural resource, no alternatives may exist, so scarcity will drive up the price, shortly before the good extinguishes (Roberts et al., 2018; Yarlik, Filis, Lloyd \& Degiannakis, 2018; Zhang, 2018). Derived from this insight, the model will be based on the maximum temperature for agricultural goods and industry production as well as time for extinction of natural resources and cooling and storage maximum temperatures in order to determine market transition and shifting trends but also price spikes and peaks based on the world and regional temperatures.

\section{Data study 1: Climate change induced market flows}

In order to operationalize and consolidate the underlying premise that countries that economically benefit from climate change feature a better market prospects, worldwide Foreign Direct Investment (FDI) flows ${ }^{5}$ (Hypothesis $\mathrm{H}_{1.1}$ ), remittances ${ }^{6}$ (Hypothesis $\mathrm{H}_{2.1}$ ), and internet connectivity ${ }^{7}$ (Hypothesis $\mathrm{H}_{3.1}$ ), were retrieved online form the World Bank database for the year 2015 as well as the Global Connectivity Index homepage as an indicator of market relevance and innovation potential.

\section{Results study 1: Climate change induced market flows Climate change winners and losers model}

The relation of climate change gains and losses and market prospects was investigated. Based on the climate change winners and losers model (Puaschunder, forthcoming b), gaining and losing from climate change was related to human migration, financial inflows as well as innovation.

Human migration: When investigating the relation of human migration and climate change winners and losers in 187 countries of the world, a highly significant correlation ( $r$ Pearson(187) $=.184, p<.006)$, is found between being climate change winner and human migration inflows. A highly significant independent t-test with $t(185)=-2.401, p=0.017$ of 110 climate change loser and 77 winner countries consolidates the finding (Puaschunder, forthcoming b).

Financial inflows: When investigating the relation of financial inflows and climate change winners and losers including 181 countries of the world, a significant correlation ( $r$ Pearson(181) $=.180, p<.016)$, is found between being climate change winner and FDI inflows. A highly significant independent t-test with $t(179)=2.680, p=0.008$ of 110 climate change loser and 77 winner countries consolidates the finding. As a cross validation of lasting financial

\footnotetext{
${ }^{5}$ http://data.worldbank.org/indicator/BX.KLT.DINV.CD.WD

${ }^{6}$ http://data.worldbank.org/indicator/BX.TRF.PWKR.CD.DT

${ }^{7}$ http://www.huawei.com/minisite/gci/en/country-rankings.html
} 
inflows into climate change winner countries, a non-significant correlation and non-significant independent t-tests are reported (Puaschunder, forthcoming b).

Innovation: When investigating the innovation potential currently prevalent in climate change winners and losers including 79 countries of the world, a significant correlation ( $r$ Pearson(79) $=.507, p<.000)$, is found between being climate change winner and global connectivity as measured by the 2018 Global Connectivity Index. ${ }^{8}$ A highly significant independent t-test with $t(77)=6.306, p=0.000$ of 33 climate change loser and 46 winner countries consolidates the finding.

\section{Data study 2: Climate flexibility}

Climate change was recently found to affect countries differently (Puaschunder, forthcoming b). Given different mean temperatures and GDP compositions, countries around the globe will be affected differently by a warming climate (Puaschunder, forthcoming b). In the determination into climate change gain and loss prospects, climate flexibility needs to be integrated. Climate flexibility is defined as leeway countries have in coping with a changing climate due to a range of climate zones prevalent in their territory. Climate flexibility can be grounded on the relative latitude and altitude of countries around the globe. The wider the range of latitude and altitude within a nation state, the more climate flexibility and favorable economic leeway of degrees of freedom for multiple production peaks is assumed. When dividing the world given temperature ranges prevalent calculated based on the List of Countries by Extreme Temperatures, ${ }^{9}$ the following temperature ranges are found as exhibited in table 3.

\section{Results study 2: Climate flexibility}

Table 3 exhibits 87 countries' temperature range in comparison to each other. One third of the sample features countries with the widest temperature range and therefore most flexible in green color, one third of the sample features medium temperature range of climate flexibility in yellow color and one third of the sample with lowest temperature range and relative climate inflexibility in red color...

8 http://www.huawei.com/minisite/gci/en/country-rankings.html

${ }^{9}$ https://en.wikipedia.org/wiki/List_of_countries_by_extreme_temperatures 


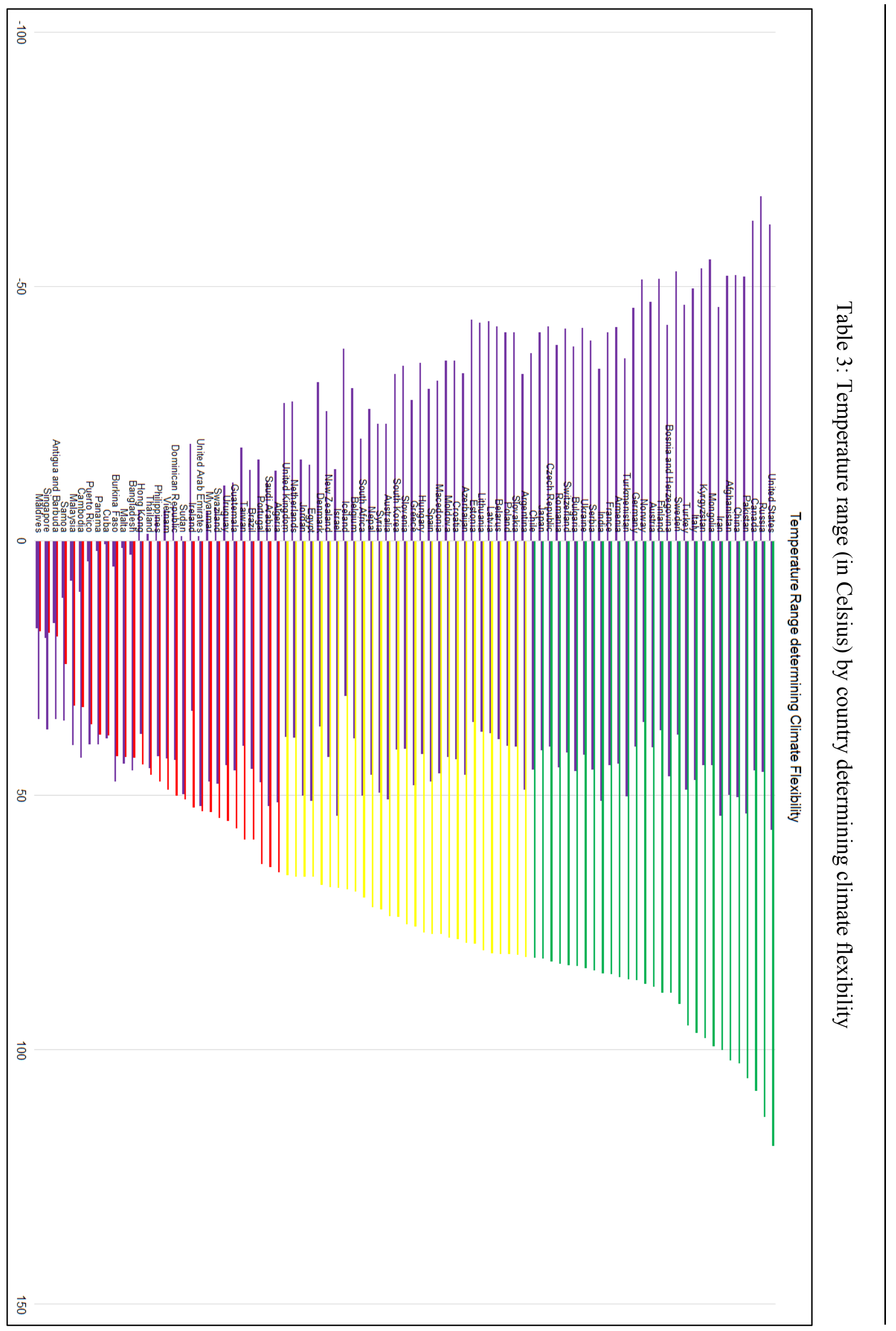


The United States (US) leads on climate flexibility with a temperature range of $r=118.9^{\circ} \mathrm{C}$ based on [-62.2 having been the lowest temperature ever recorded in the US and $56.7^{\circ} \mathrm{C}$ the highest temperature ever recorded in the US], followed by Russia $r=113.2^{\circ} \mathrm{C}$ based on $\left[-67.8 ; 45.4^{\circ} \mathrm{C}\right]$, Canada $r=108^{\circ} \mathrm{C}$ based on $\left[-63 ; 45^{\circ} \mathrm{C}\right]$, Pakistan $r=105.5^{\circ} \mathrm{C}$ based on $\left[-52 ; 53.5^{\circ} \mathrm{C}\right]$, China $r=102.6^{\circ} \mathrm{C}$ based on $\left[-52.3 ; 50.3^{\circ} \mathrm{C}\right]$, Afghanistan $r=102.6^{\circ} \mathrm{C}$ based on $\left[-52.2 ; 49.9^{\circ} \mathrm{C}\right]$, Iran $r=100^{\circ} \mathrm{C}$ based on $\left[-46 ; 54^{\circ} \mathrm{C}\right]$, Mongolia $r=99.3^{\circ} \mathrm{C}$ based on $\left[-55.3 ; 44^{\circ} \mathrm{C}\right]$, Kyrgyzstan $r=97.6^{\circ} \mathrm{C}$ based on $\left[-53.6 ; 44^{\circ} \mathrm{C}\right]$, Italy $r=96.6^{\circ} \mathrm{C}$ based on $\left[-49.6 ; 47^{\circ} \mathrm{C}\right]$, Turkey $r=95.2^{\circ} \mathrm{C}$ based on $[-46.4$; $\left.48.8^{\circ} \mathrm{C}\right]$, Sweden $r=91^{\circ} \mathrm{C}$ based on $\left[-53 ; 38^{\circ} \mathrm{C}\right]$, Finland $r=88.7^{\circ} \mathrm{C}$ based on $\left[-51.5 ; 37.2^{\circ} \mathrm{C}\right]$, Bosnia and Herzegovina $r=88.7^{\circ} \mathrm{C}$ based on $\left[-42.5 ; 46.2^{\circ} \mathrm{C}\right]$, Austria $r=87.6^{\circ} \mathrm{C}$ based on $\left[-47.1 ; 40.5^{\circ} \mathrm{C}\right]$, Norway $r=87^{\circ} \mathrm{C}$ based on $\left[-51.4 ; 35.6^{\circ} \mathrm{C}\right]$, Germany $r=86.2^{\circ} \mathrm{C}$ based on $\left[-45.9 ; 40.3^{\circ} \mathrm{C}\right]$, Turkmenistan $r=86.1^{\circ} \mathrm{C}$ based on $\left[-36 ; 50.1^{\circ} \mathrm{C}\right]$, Armenia $r=85.7^{\circ} \mathrm{C}$ based on $\left[-42 ; 43.7^{\circ} \mathrm{C}\right]$, France $r=85.1^{\circ} \mathrm{C}$ based on $\left[-41 ; 44.1^{\circ} \mathrm{C}\right]$, India $r=84.9^{\circ} \mathrm{C}$ based on $\left[-33.9 ; 51^{\circ} \mathrm{C}\right]$, Serbia $r=84.4^{\circ} \mathrm{C}$ based on $\left[-39.5 ; 44.9^{\circ} \mathrm{C}\right]$, Ukraine $r=83.9^{\circ} \mathrm{C}$ based on $\left[-41.9 ; 42^{\circ} \mathrm{C}\right]$, Bulgaria $r=83.5^{\circ} \mathrm{C}$ based on $\left[-38.3 ; 45.2^{\circ} \mathrm{C}\right]$, Switzerland $r=83.3^{\circ} \mathrm{C}$ based on $\left[-41.8 ; 41.5^{\circ} \mathrm{C}\right]$, Romania $r=83^{\circ} \mathrm{C}$ based on [$38.5 ; 44.5^{\circ} \mathrm{C}$ ], Czech Republic $r=82.6^{\circ} \mathrm{C}$ based on $\left[-42.2 ; 40.4^{\circ} \mathrm{C}\right]$, Japan $r=82.1^{\circ} \mathrm{C}$ based on [-41; $\left.41^{\circ} \mathrm{C}\right]$ and Chile $r=81.9^{\circ} \mathrm{C}$ based on $\left[-37 ; 44.9^{\circ} \mathrm{C}\right]$.

In the medium climate flexibility range are Argentina with $r=81.7^{\circ} \mathrm{C}$ based on $\left[-32.8 ; 48.9^{\circ} \mathrm{C}\right]$, Slovakia $r=81.3^{\circ} \mathrm{C}$ based on $\left[-41 ; 40.3^{\circ} \mathrm{C}\right]$, Poland $r=81.2^{\circ} \mathrm{C}$ based on $\left[-41 ; 40.2^{\circ} \mathrm{C}\right]$, Belaruse $r=81.1^{\circ} \mathrm{C}$ based on $\left[-42.2 ; 38.9^{\circ} \mathrm{C}\right]$, Latvia $r=81^{\circ} \mathrm{C}$ based on $\left[-43.2 ; 37.8^{\circ} \mathrm{C}\right]$, Lithuania $r=80.4^{\circ} \mathrm{C}$ based on $\left[-42.9 ; 37.5^{\circ} \mathrm{C}\right]$, Estonia $r=79.1^{\circ} \mathrm{C}$ based on $\left[-43.5 ; 35.6^{\circ} \mathrm{C}\right]$, Azerbaijan $r=79^{\circ} \mathrm{C}$ based on $\left[-33 ; 46^{\circ} \mathrm{C}\right]$, Croatia $r=78.3^{\circ} \mathrm{C}$ based on $\left[-35.5 ; 42.8^{\circ} \mathrm{C}\right]$, Moldova $r=77.9^{\circ} \mathrm{C}$ based on $[-35.5$; $\left.42.4^{\circ} \mathrm{C}\right]$, Spain $r=77.2^{\circ} \mathrm{C}$ based on $\left[-30 ; 47.2^{\circ} \mathrm{C}\right]$, Macedonia $r=77.2^{\circ} \mathrm{C}$ based on $\left[-31.5 ; 45.7^{\circ} \mathrm{C}\right]$, Hungary $r=76.9^{\circ} \mathrm{C}$ based on $\left[-35 ; 41.9^{\circ} \mathrm{C}\right]$, Greece $r=75.8^{\circ} \mathrm{C}$ based on $\left[-27.8 ; 48^{\circ} \mathrm{C}\right]$, Slovenia $r=75.3^{\circ} \mathrm{C}$ based on $\left[-34.5 ; 40.8^{\circ} \mathrm{C}\right]$, South Korea $r=73.8^{\circ} \mathrm{C}$ based on $\left[-32.8 ; 41^{\circ} \mathrm{C}\right]$, Australia $r=73.7^{\circ} \mathrm{C}$ based on $\left[-23 ; 50.7^{\circ} \mathrm{C}\right]$, Syria $r=72.4^{\circ} \mathrm{C}$ based on $\left[-23 ; 49.4^{\circ} \mathrm{C}\right]$, Nepal $r=72^{\circ} \mathrm{C}$ based on $\left[-26 ; 46^{\circ} \mathrm{C}\right]$, South Africa $r=70.1^{\circ} \mathrm{C}$ based on $\left[-20.1 ; 50^{\circ} \mathrm{C}\right]$, Iceland $r=68.4^{\circ} \mathrm{C}$ based on $[-37.9$; $30.5^{\circ} \mathrm{C}$ ], Israel $r=68.2^{\circ} \mathrm{C}$ based on $\left[-14.2 ; 54^{\circ} \mathrm{C}\right]$, New Zealand $r=68^{\circ} \mathrm{C}$ based on $\left[-25.6 ; 42.4^{\circ} \mathrm{C}\right]$, Denmark $r=67.6^{\circ} \mathrm{C}$ based on $\left[-31.2 ; 36.4^{\circ} \mathrm{C}\right]$, Netherlands $r=66^{\circ} \mathrm{C}$ based on $\left[-27.4 ; 38.6^{\circ} \mathrm{C}\right]$, Jordan $r=66^{\circ} \mathrm{C}$ based on $\left[-16 ; 50^{\circ} \mathrm{C}\right]$, Egypt $r=66^{\circ} \mathrm{C}$ based on $\left[-15 ; 51^{\circ} \mathrm{C}\right]$, and United Kingdom $r=65.7^{\circ} \mathrm{C}$ based on $\left[-27.2 ; 38.5^{\circ} \mathrm{C}\right]$.

The least climate flexibility have Algeria $r=65.1^{\circ} \mathrm{C}$ based on $\left[-13.8 ; 51.3^{\circ} \mathrm{C}\right]$, Saudi Arabia $r=64^{\circ} \mathrm{C}$ based on $\left[-12 ; 52^{\circ} \mathrm{C}\right]$, Portugal $r=63.4^{\circ} \mathrm{C}$ based on $\left[-16 ; 47.4^{\circ} \mathrm{C}\right]$, Brazil $r=58.7^{\circ} \mathrm{C}$ based on $[-14$; $\left.44.7^{\circ} \mathrm{C}\right]$, Taiwan $r=58.6^{\circ} \mathrm{C}$ based on $\left[-18.4 ; 40.2^{\circ} \mathrm{C}\right]$, Guatemala $r=56.5^{\circ} \mathrm{C}$ based on $\left[-11.5 ; 45^{\circ} \mathrm{C}\right]$, Uruguay $r=55^{\circ} \mathrm{C}$ based on $\left[-11 ; 44^{\circ} \mathrm{C}\right]$, Swaziland $r=54.4^{\circ} \mathrm{C}$ based on $\left[-6.7 ; 47.7^{\circ} \mathrm{C}\right]$, Myanmar $r=53.2^{\circ} \mathrm{C}$ based on $\left[-6 ; 47.2^{\circ} \mathrm{C}\right]$, United Arab Emirates $r=53.1^{\circ} \mathrm{C}$ based on $\left[-1 ; 52.1^{\circ} \mathrm{C}\right]$, Ireland $r=52.4^{\circ} \mathrm{C}$ based on $\left[-19.1 ; 33.3^{\circ} \mathrm{C}\right]$, Sudan $r=50.7^{\circ} \mathrm{C}$ based on $\left[-1 ; 49.7^{\circ} \mathrm{C}\right]$, Dominican Republic $r=50^{\circ} \mathrm{C}$ based on $\left[-7 ; 43^{\circ} \mathrm{C}\right]$, Vietnam $r=48.8^{\circ} \mathrm{C}$ based on $\left[-6.1 ; 42.7^{\circ} \mathrm{C}\right]$, Philippines $r=47.2^{\circ} \mathrm{C}$ based on $\left[-5 ; 42.2^{\circ} \mathrm{C}\right]$, Thailand $r=46^{\circ} \mathrm{C}$ based on $\left[-1.4 ; 44.6^{\circ} \mathrm{C}\right]$, Hong Kong $r=43.9^{\circ} \mathrm{C}$ based on [6 ; $\left.37.9^{\circ} \mathrm{C}\right]$, Bangladesh $r=42.5^{\circ} \mathrm{C}$ based on $\left[2.6 ; 45.1^{\circ} \mathrm{C}\right.$ ], Malta $r=42.4^{\circ} \mathrm{C}$ based on $\left[1.4 ; 43.8^{\circ} \mathrm{C}\right]$, Cuba $r=38.2^{\circ} \mathrm{C}$ based on $\left[0.6 ; 38.8^{\circ} \mathrm{C}\right]$, Panama $r=38^{\circ} \mathrm{C}$ based on $\left[2 ; 40^{\circ} \mathrm{C}\right]$, Puerto Rico $r=36^{\circ} \mathrm{C}$ based on $\left[4 ; 40^{\circ} \mathrm{C}\right.$ ], Cambodia $r=32.6^{\circ} \mathrm{C}$ based on $\left[10 ; 42.6^{\circ} \mathrm{C}\right.$ ], Malaysia $r=32.3^{\circ} \mathrm{C}$ based on [7.8; $40.1^{\circ} \mathrm{C}$, Samoa $r=24.2^{\circ} \mathrm{C}$ based on $\left[11.1 ; 35.3^{\circ} \mathrm{C}\right]$, Antigua and Barbuda $r=18.8^{\circ} \mathrm{C}$ based on $\left[16.1 ; 34.9^{\circ} \mathrm{C}\right]$, Singapore $r=18^{\circ} \mathrm{C}$ based on $\left[19 ; 37^{\circ} \mathrm{C}\right.$ ], Maldives $r=17.7^{\circ} \mathrm{C}$ based on [17.2; $34.9^{\circ} \mathrm{C}$, and Burkina Faso $r=6.2^{\circ} \mathrm{C}$ based on $\left[41 ; 47.2^{\circ} \mathrm{C}\right]$,

Climate flexibility is prospected to open a gate for productivity. Countries with climate flexibility are likely be productive grounds for agriculture, industry and service production at all different temperature levels. 


\section{Climate flexibility model}

The relation of climate flexibility and market prospects was investigated. Based on the determined climate flexibility, the range of temperature variability - as retrieved and calculated based on the List of Countries by Extreme Temperatures ${ }^{10}$ - was related to human migration.

Human migration: When investigating the relation of human migration and climate flexibility in 86 countries of the world, a highly significant correlation ( $r$ Pearson $(86)=.319, p<.002)$, is found between being climate flexible and human migration inflows. No significant relation is reported for financial inflows as well as innovation.

\section{Data study 3: Climate change expectations driving commodity bubbles}

The world is divided in nation states. Recent research has defined climate change winners and losers by GDP prospects in a changing climate (Puaschunder, forthcoming b). Now by stepping aside from national territories, climate change winning industries and sectors were unraveled most recently (Puaschunder, work in progress).

\section{Results study 3: Climate change expectations driving commodity bubbles}

For the GDP comprising pillars of agriculture, industry and service sectors, the peak temperatures for production were derived from a meta-analysis of literature sources. For agriculture, crop durability - meaning how long crops can prosper in a changing climate - was determined based on literature resources. Graph 5 holds crops and their germination temperature, peak performance temperature and maximum possible temperature. 
Graph 5: Agriculture sector temperature-based condition in relation to world mean temperature

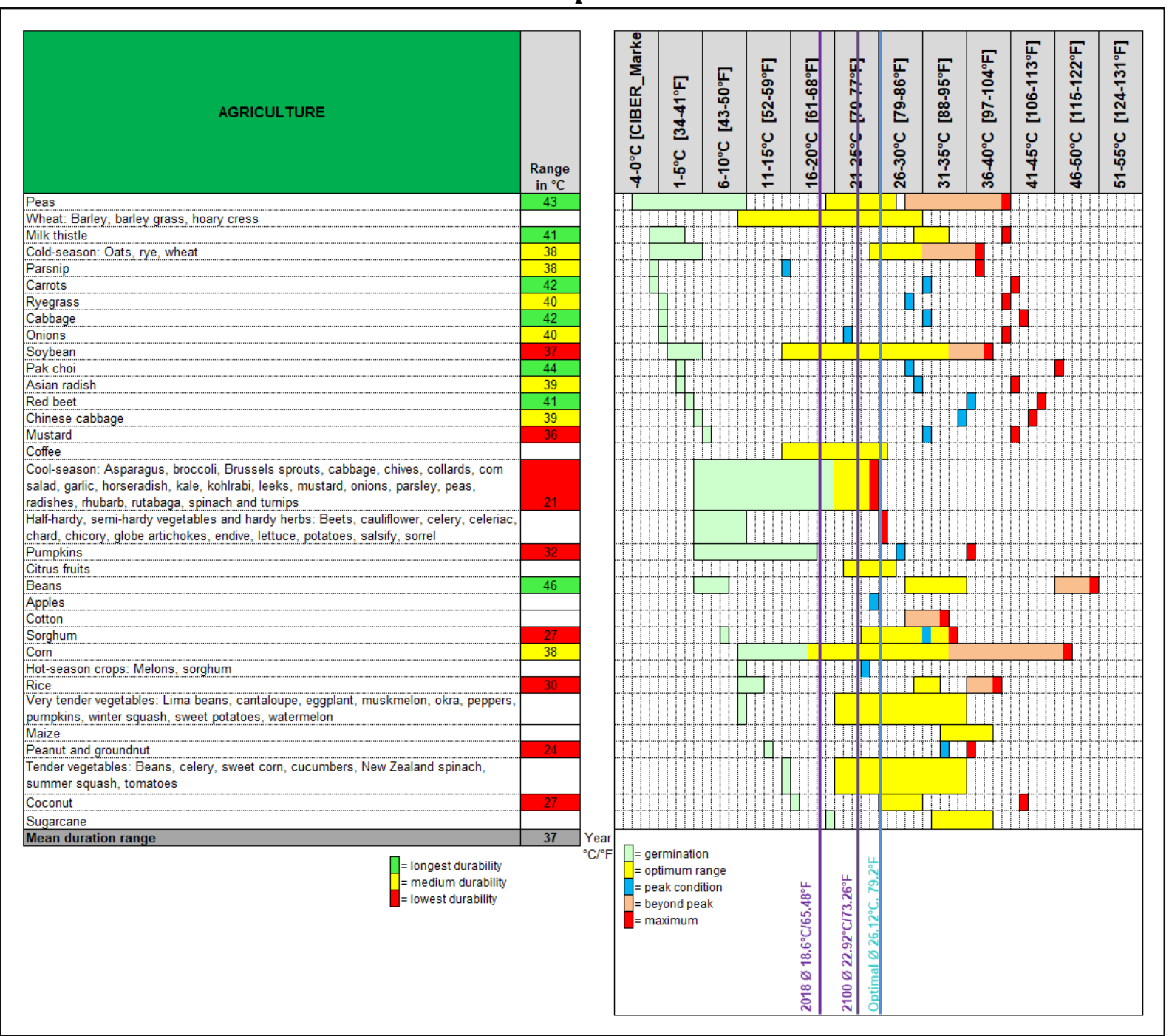

The temperature ranges are outlined in graph 6, which holds the crop durability. Longest temperature range crops are indicated by green color, medium temperature range in yellow color and shortest temperature range in red color. 


\section{Graph 6: Temperature ranges for outlining agriculture durability}

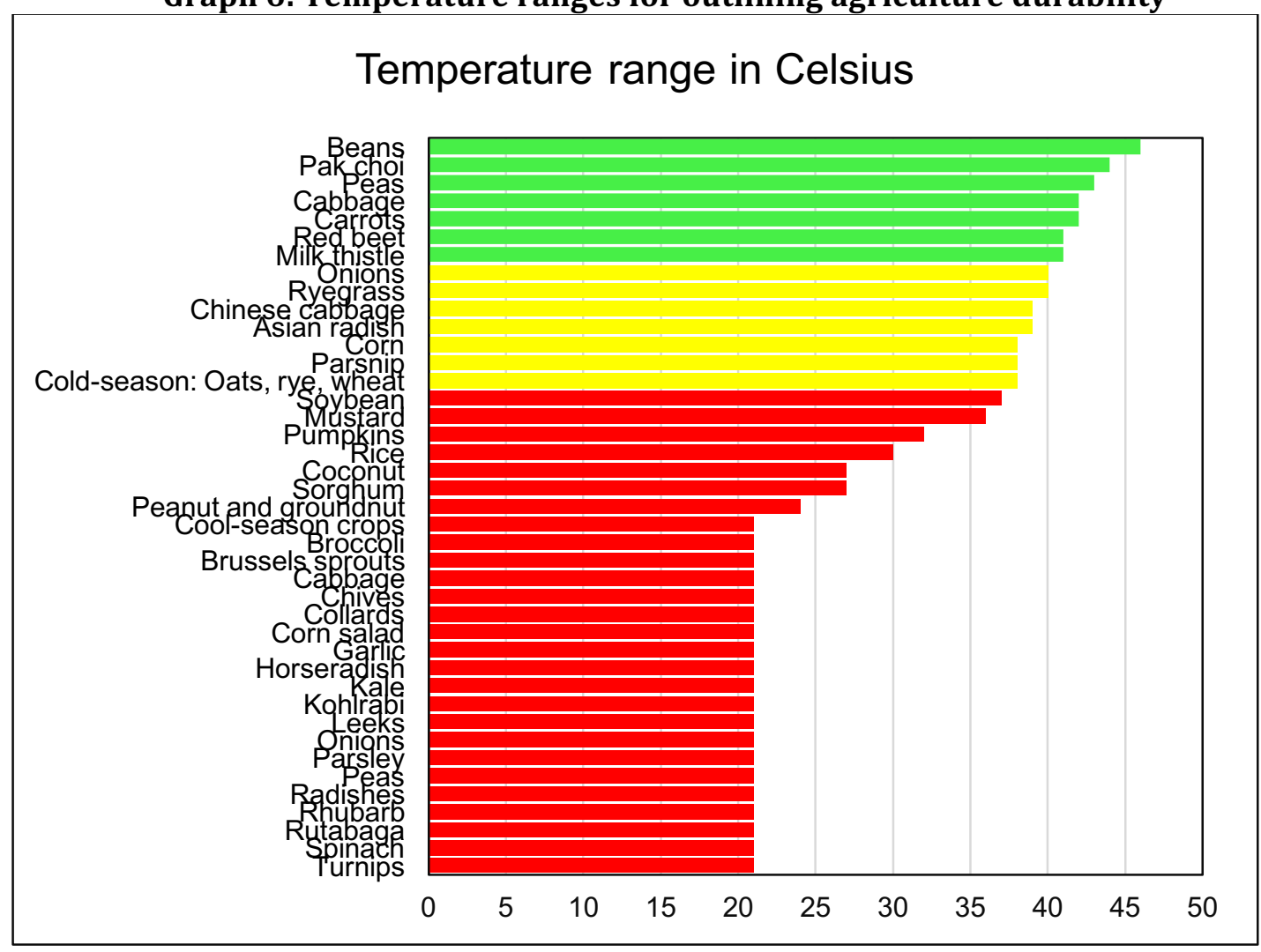

Beans, pak choi, peas, cabbage, carrots, red beet and milk thistle will have the widest application range - as outlined in green color - regarding temperature. Onions, ryegrass, Chinese cabbage, Asian radish, corn, parsnips and cold-season crops such as oats, rye and wheat have a medium flexibility range - as exhibited in yellow color - when it comes to temperature. Soybean, mustard, pumpkins, rice, coconut, sorghum, peanut and groundnut but also all the cool-season crops such as broccoli, Brussels sprouts, cabbage, chieves, collards, corn salad, garlic, horseradish, kale, kohlrabi, leeks, onions, parsley, peas, radishes, rhubarb, rutabaga, spinach and turnips will run out of time first as outlined in red coloring of the smallest temperature range. The latter's cultivation is expected to become the most expensive first, then the medium and then the longest temperature-ranged crops.

Given the assumption of price increases around scarcity, a model for crops' extinction and price mechanism is sketched out (Figuerola-Ferretti \& Cervera, 2018; Kaabia et al., 2018; Lips, 2018). In the oil energy sector, price spikes have been found around procurement shortages, which are expected to be occurring in all climate-related extinction cases (Roberts et al., 2018).

Time series of commodity price indices from June 1989 to 2017 retrieved from Index Mundi, ${ }^{11}$ allowed to determine the price development of commodity prices for food and beverages. Since the turn of the millennium, temperature records have skyrocketed, which fueled vast communication about global warming. Price expectations are therefore assumed to have spiraled a commodities bubble for food and beverages. As outlined in graph 7, commodity prices for food as represented by barley, Canadian wheat, maize/corn, rice, soft red winter wheat, and sorghum have risen extraordinarily since 2000. 
(5) Jun-10

을 Dec-10

ᄃ Jun-11

3 Dec-11

| Jun-12

$\sum$ Jun-13

Dec-13

Jun-14

Dec-14

Jun-15

Dec-15

Jun-16

Dec-16

Jun-17

Dec-17

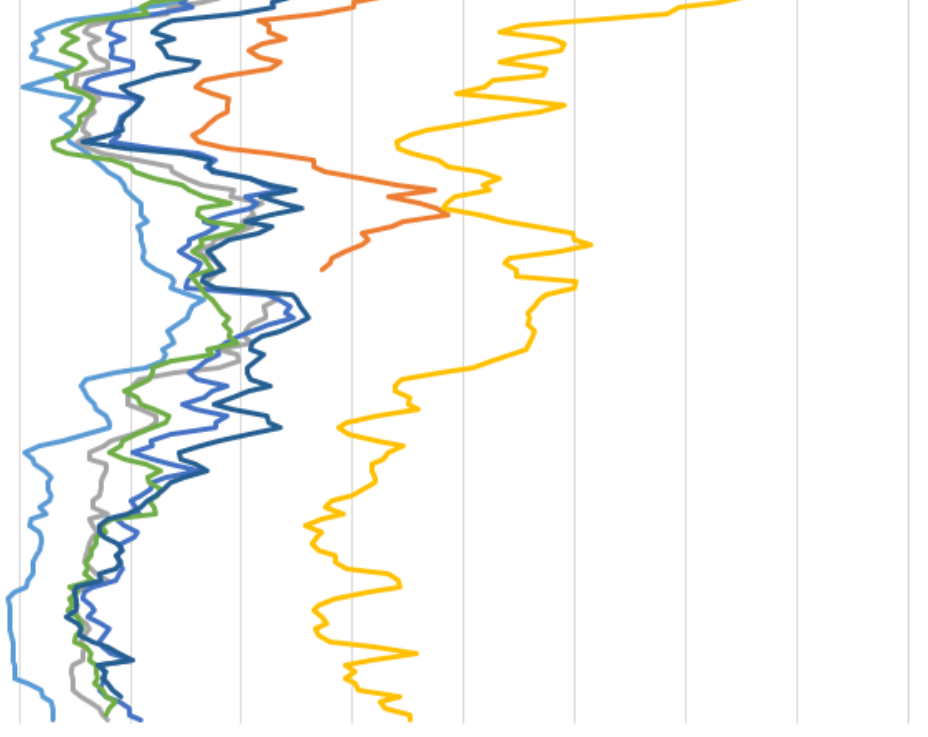

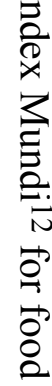


की Jun-09

Dec-09

Jun-10

Dec-10

Jun-11

Dec-11

Jun-12

Dec-12

Jun-13

Dec-13

Jun-14

Dec-14

Jun-15

Dec-15

Jun-16

Dec-16

Jun-17

Dec-17

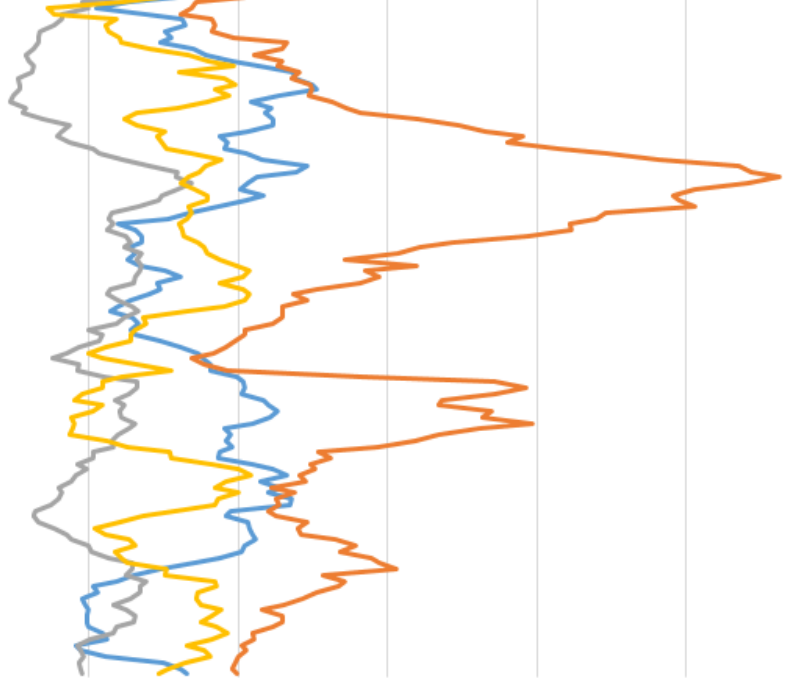

을

尺्ञ 
Highly significant independent t-tests comparing the price index per crop prior to 2000 and thereafter consolidate the extraordinary price rise in commodities for barley with $t(358)=-$ 11.984, $p=0.000$ of 139 data points in the previous millennium and 221 observations in the current millennium based on monthly price indices measurement; Canadian wheat with $t(284)=-7.502, p=0.000$ of 139 data points in the previous millennium and 147 observations in the current millennium based on monthly price indices measurement; maize/corn with $t(358)=-8.82, p=0.000$ of 139 data points in the previous millennium and 221 observations in the current millennium based on monthly price indices measurement; rice with $t(358)=-7.331$, $p=0.000$ of 139 data points in the previous millennium and 221 observations in the current millennium based on monthly price indices measurement; soft red winter wheat with $t(358)=-$ 8.786, $p=0.000$ of 139 data points in the previous millennium and 221 observations in the current millennium based on monthly price indices measurement; sorghum with $t(357)=-$ 10.352, $p=0.000$ of 139 data points in the previous millennium and 220 observations in the current millennium based on monthly price indices measurement; wheat with $t(355)=-9.209$, $p=0.000$ of 139 data points in the previous millennium and 218 observations in the current millennium based on monthly price indices measurement; cocoa bean with $t(358)=-13.702$, $p=0.000$ of 139 data points in the previous millennium and 221 observations in the current millennium based on monthly price indices measurement; Arabica coffee with $t(358)=-3.631$, $p=0.000$ of 139 data points in the previous millennium and 221 observations in the current millennium based on monthly price indices measurement; and tea with $t(358)=-11.493$, $p=0.000$ of 139 data points in the previous millennium and 221 observations in the current millennium based on monthly price indices measurement. Out of all commodity indices for food and beverage reported in the Index Mundi database ${ }^{14}$ with sufficient data points, Robusta coffee was the only good with non-significant price increases for the period after the turn of the millennium. To cross-validate the findings, price indices for gasoline, medical care, fast food, soda, jewelery, new cars and computers ${ }^{15}$ were eyeballed and no stringent pattern of increased prices could be found for these goods and services since turn of the millennium.

Given the back-testing results consolidating inflated commodity prices since the turn of the millennium, future prospects of price deviations based on the extinction temperature are drawn as stylized, hypothetical estimation. Graph 9 holds prospective extinction based market price predictions as deviations from normal prices. As one can see, the world with medium temperature of $18.6^{\circ} \mathrm{C}$ is not at the efficiency frontier yet (Foley, 2007). In addition, the mean temperature for continents was derived from literature and critical mean continental temperature in Central and South America, Africa and Australia put into perspective.

\footnotetext{
${ }^{14}$ https://www.indexmundi.com/commodities/?commodity=wheat\&months=360
}

15 https://people.duke.edu/ rnau/411infla.htm 


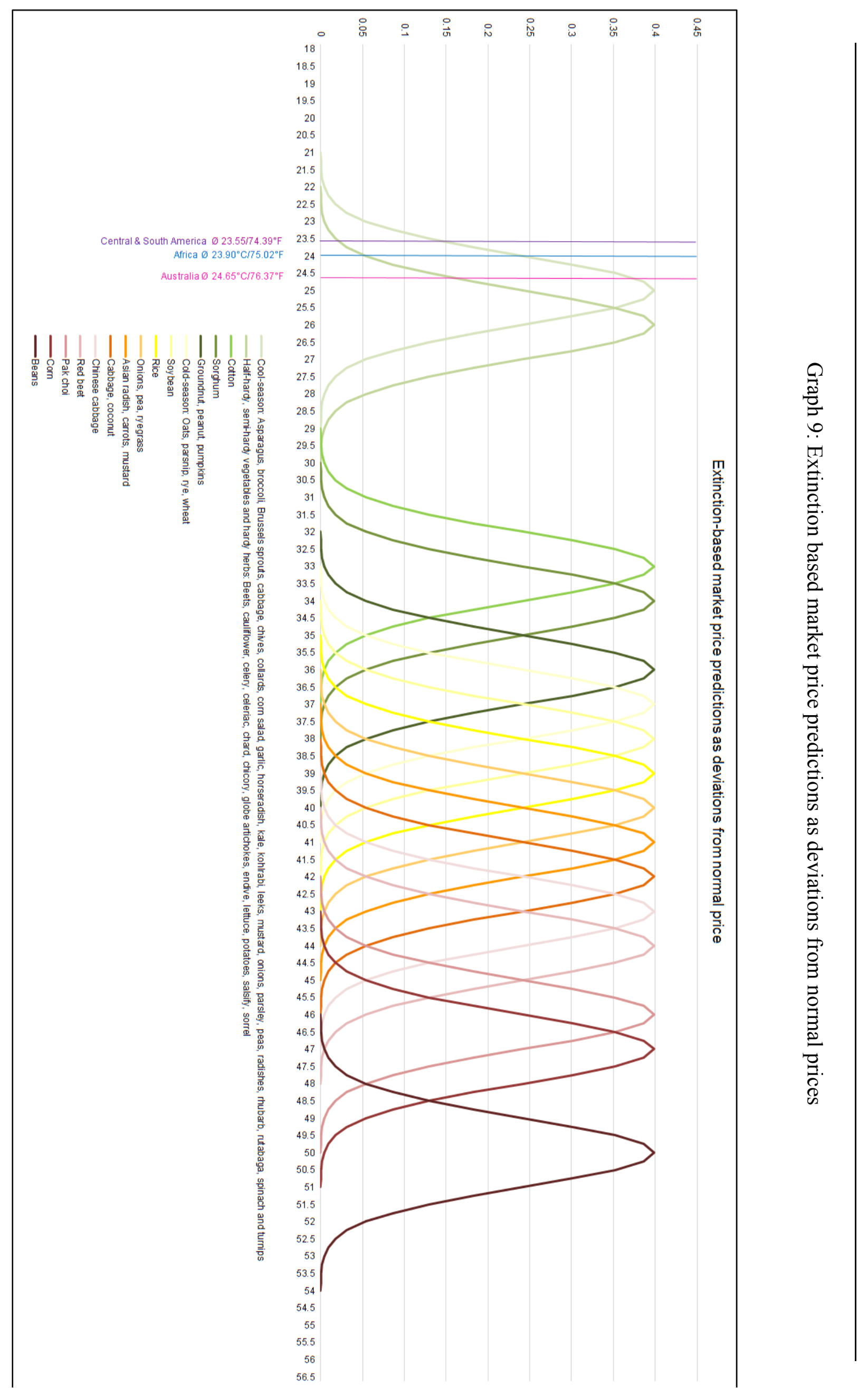




\section{RESULTS DISCUSSION}

The presented results may shed light on the climate change from a different angle and grant hope but also alleviate the contemporary reported predicament of economic growth versus sustainability (Zhou, Smulders \& Gerlagh, 2018; Täuber, van Zomeren \& Kutlaca, 2015). Behavioral economics found people to be risk-averse and their loss prospects loom larger than gains (Kahneman \& Tversky, 1979; Tversky \& Shafir, 1992). Changing individual temperature conditions make people afraid and there is an immediate loss of the status-quo visible. But in reality, the world by itself will be winning from a warming globe for quite some time, just needs to relocate and transfer skills and production into those areas that will become newly arable and pleasant to stay and work in (Puaschunder, forthcoming b, work in progress).

Looking forward to world peak condition in regards to a favorable climate for GDP production, the future wealth of nations may be determined by countries' access to global markets (e.g., via infrastructure such as airports and ports, trade relations such as general agreements and trade unions and practiced customs such as openness to take in migrants or a favorable easily to obtain language like English or Spanish) as well as natural propensities to temperature flexibility by being either a wide-spread country (like Canada or Russia) or featuring different temperature zones due to tectonic landscape formation and altitude (e.g., like Italy, New Zealand, Luxembourg or Switzerland featuring mountains).

Future favorable market operations appear to be (1) investments in insurances specializing on climate change and capitalizing the collective fear that has been built around the change in temperature, which actually also features positive aspects (Puaschunder, forthcoming b, work in progress). (2) Mergers and conglomerates of multiple entities to diversify from climaterelated risks and shortages with higher economies of scale (Emmert, 2018). (3) Surge price strategies as ticket prices that can offer a discount during shoulder seasons disrupted from unfavorable climate and high prices during peak seasons. The winter sports industry appears to heading towards a direction of high luxury price and low customer base due to snow shortages and shortened winter seasons (Emmert, 2018). Mountain ownership by insurance agencies is another trend that is seen in the winter industry (Emmert, 2018). Resorts have immensely high insurance costs, both for bodily injury and weather. If a resort can farm their insurance in house, they can save in the long run. This trend may also be extended onto other industries that may become more intwined with insurances as climate change causes weather unpredictability. Consumer lock-in strategies but also weather-related loss exemptions for satisfaction guarantee clauses may be additional trends we are heading towards in the age of global warming. Revenue off weather-dependent sales are potential other areas that are prospected to see economic growth in times of weather uncertainty caused by climate change. For instance, in the skiing industry buy now half of the revenue is made up with food, lodging, rentals and lesson sales (Emmert, 2018).

\section{DISCUSSION AND FUTURE OUTLOOK}

Overall, the market-driven results of price mechanisms but also FDI and market streams underline the importance of research on the effect of climate change on market mechanisms. This first preliminary introduction of the idea of climate flexibility as future determinant of competitive advantage and wealth of nations opens a door for future research on climate impacts on international trade. The impact of climate on markets also implicitly calls for a further investigation of industrial policies that rest on the fundamental insight that market prices are not often not sufficient in allocating scarce resources in a humane society (Altenburg \& Assmann, 2018). For instance, preferenes of future generations cannot be fully reflected in market prices (Altenburg \& Rodrik, 2018). 
As a caveat to the presented results, it deserves mentioning that price expectations - to this day - are hard to predict and the actual temporal flow of these recurrent patterns is hard to measure quantitatively. While there is a pattern of the economy, problem of agents remain to distinguish between noise and information, distinguish between shocks and change. In the ever-changing nature of capitalism, having evolved from industrialization to post-World War booms to globalization and the new media revolution, the cycles have become more fuzzy and unpredictable (Held \& McGrew, 2007).

Future research may investigate climate change impacts on the "demand" side of economic pricing behavior. As studies have shown, demand preferences are sticky as habits usually form over a long time and therefore do not change quickly. Future studies may unravel how climate changes preferences for specific goods and services in the long run. Thereby, especially the role of critical life events and external climate shocks in changing preferences immediately and definitively should be scrutinized by behavioral insights specialists targeting at finding innovative ways how to align the demand side with the supply side of climate policies from an inter-disciplinary perspective. Future studies may also focus on how to teach the gains of a warming earth in applied business cases (Gonglewski \& Helm, 2010; Helm, 2009). All these presented insights gained may help administer the transition to new technologies and renewable energy as well as reap the economic benefits of a warming globe.

\section{References}

Acevedo, S., Mrkaic, M, Novta, N., Poplawski-Ribeiro, M., Pugacheva, E. \& Topalova, P. (2018). How can low income countries cope? The effects of weather shocks on economic activity. Presentation delivered at The New School Economics of Climate Change Project, New York: The New School, April 12.

Altenburg, T. \& Assmann, C. (2018). United Nations Environment Programme Report on Green Industrial Policy: Concept, Policies, Country Experiences (2018). Geneva, Bonn: United Nations: United Nations Environment Programme \& German Development Institute / Deutsches Institut für Entwicklungspolitik.

Altenburg, T. \& Rodrik, D. (2018). Green industrial policy: Accelerating structural change towards wealthy green economies. In T. Altenburg \& C. Assmann (Eds.), United Nations Environment Programme Report on Green Industrial Policy: Concept, Policies, Country Experiences, pp. 2-20. Geneva, Bonn: United Nations: United Nations Environment Programme \& German Development Institute / Deutsches Institut für Entwicklungspolitik.

Andreoni, J., Erard, B. \& Feinstein, J.S. (1998). Tax compliance. Journal of Economic Literature, 36, 2, 818-860.

Asmundson, I. (2017). Financial services: Getting the goods. IMF entry retrieved from http://www.imf.org/external/pubs/ft/fandd/basics/finserv.htm

Bai, S., Koong, K. \& Valenzuela, E. (2018). The dynamic impact of oil price shocks on stock returns: Evidence from U.S. energy companies in the value chain. $6^{\text {th }}$ International Symposium on Environment Energy \& Finance Issues, ISEFI 2018, Paris, France, May 24-25.

Barro, R. (1990). Government spending in a simple model of endogenous growth. Journal of Political Economy, 98, 103-125.

Bienenfeld, M. (1988). Regularity in price changes as an effect of changes in distribution. Cambridge Journal of Economics, 12, 247-255.

Bonato, M. (2018). Realized correlations, betas and volatility spillover in the agricultural commodity market: What has changed? $6^{\text {th }}$ International Symposium on Environment Energy \& Finance Issues, ISEFI 2018, Paris, France, May 24-25.

Bürgenmeier, B. (1994). Environmental policy: Beyond the economic dimension. In B. Bürgenmeier (Ed.), Economy, environment, and technology: A socio-economic approach, pp. 166-175. New York, NY: Armonk Sharpe.

Burke, M., Hsiang, S.M. \& Miguel, E. (2015). Global non-linear effect of temperature on economic production. Nature, 527, 235-239.

Centeno, M.A., Creager, A.N., Elga, A., Felton, E., Katz, St.N., Massey, W.A. \& Shapiro, J.N. (2013). Global systemic risk: Proposal for a research community. Princeton University, NJ: Princeton Institute for International and Regional Studies working paper. 
Centeno, M.A., \& Tham, A. (2012).The emergence of risk in the global system. Princeton, NJ: Princeton University working paper.

Chancel, L. \& Piketty, Th. (2015). Carbon and inequality: From Kyoto to Paris. Paris, France: Paris School of Economics.

Chilcote, E.B. (1997). Interindustry structure, relative prices, and productivity: An input-output study of the U.S. and O.E.C.D countries. Doctoral Thesis. New York, NY: The New School for Social Research Department of Economics.

Cialdini, R.B. (1996). Social influence and the triple tumor structure of organizational dishonesty. In D.M. Messick and A.E. Tenbrunsel (Eds.), Codes of Conduct, pp. 44-58. New York, NY: Sage.

Cifarelli, G. \& Paesani, P. (2018). Fundamentalists, chartists and hedgers: A non-linear dynamic model of futures oil pricing: Theory and empirical evidence. $6^{\text {th }}$ International Symposium on Environment Energy \& Finance Issues, ISEFI 2018, Paris, France, May 24-25.

Cockshott, W.P. \& Cottrell, A. (1993). Towards a new socialism. Nottingham, UK: Spokesman.

Dawes, R.M. (1980). Social dilemmas. Annual Review of Psychology, 31, 1, 169-193.

Dukhanina, E., Leveque, F. \& Massol, O. (2018). Policy measures targeting a more integrated gas market: Impact on prices and arbitrage activity. Retrieved from

https://www.eeg.tuwien.ac.at/conference/iaee2017/files/paper/649_Dukhanina_fullpaper_2017-06-30_2158.pdf

Ekholm, T. (2018). Climatic cost-benefit analysis under uncertainty and learning on climate sensitivity and damages. $6^{\text {th }}$ International Symposium on Environment Energy \& Finance Issues, ISEFI 2018, Paris, France, May 2425 .

Elgouacem, A. \& Legrand, N. (2018). The delaying effect of storage on investment. Evidence from the crude oil sector. $6^{\text {th }}$ International Symposium on Environment Energy \& Finance Issues, ISEFI 2018, Paris, France, May 24-25.

Emmert, H. (2018). The melting point: The economics and environmental impact of the winter sports industry. Unpublished working paper, Economics of the Environment, The New School, New York.

Environmental Defense Fund (2018). How climate change plunders the planet: A warming earth disturbs weather, people, animals and much more. Retrieved from https://www.edf.org/climate/how-climate-change-plundersplanet

Esposito, M., Haider, A., Semmler, W. \& Samaan, D. (2018). Enhancing job creation through the green transformation. In T. Altenburg \& C. Assmann (Eds.), United Nations Environment Programme Report on Green Industrial Policy: Concept, Policies, Country Experiences, pp. 50-68. Geneva, Bonn: United Nations: United Nations Environment Programme \& German Development Institute / Deutsches Institut für Entwicklungspolitik.

Feld, L.P. \& Frey, B.S. (2002). Trust breeds trust: How taxpayers are treated. Economics of Governance, 3, 2, 87-99.

Figuerola-Ferretti, I. \& Cervera, I. (2018). Recent credit risk and bubble behavior in the corporate energy sector. Retrieved from https://repositorio.comillas.edu/jspui/handle/11531/26571

Filip, O., Janda, K., Kristoufek, L. \& Zilberman, D. (2018). Food versus fuel: An updated and expanded evidence. CAMA working paper 73. Retrieved from https://papers.ssrn.com/sol3/papers.cfm?abstract_id=3070704

Foley, D. (2007). The economic fundamentals of global warming. Santa Fe, NM: Santa Fe Instiute Working paper 0712-044. Retrieved from https://www.santafe.edu/research/results/working-papers/the-economicfundamentals-of-global-warming

Frey, B.S. (1992). Tertium datur: Pricing, regulation and intrinsic motivation. Kyklos, 45, 2, 161-184.

Frey, B.S. (1997). Not just for the money: An economic theory of personal motivation. Cheltenham, UK: Edward Elgar.

Ganepola, C., Garrett, I. \& Cho, S. (2018). Oil prices, discount rate news and cash flow news. $6^{\text {th }}$ International Symposium on Environment Energy \& Finance Issues, ISEFI 2018, Paris, France, May 24-25.

Gonglewski, M. \& Helm, A. (2010). An examination of business case methodology: Pedagogical synergies from two disciplines. Global Business Languages, 15, 3, 17-31.

Greiner, A. \& Semmler, W. (2008). The global environment, natural resources, and economic growth. Oxford, UK: Oxford University Press.

Hasseldine, J.D. (1998). Prospect theory and tax reporting decisions: Implications for tax administrators. International Bureau of Fiscal Documentation, 52, 11, 501-505. 
Puaschunder, J. M. (2019). An inquiry into the nature and causes of Climate Wealth of Nations: What temperature finance gravitates towards? Sketching a climate-finance nexus and outlook on climate change-induced finance prospects. Archives of Business Research, 7(3), $183-217$.

Held, D. \& McGrew, A.G. (2007). A new world economic order? Global markets and state power: Beyond globalization/anti-globalization: Beyond the great divide. New York, NY: Polity.

Helm, A. (2009). Global marketing classroom: Green marketing. American Marketing Association Global SIG Newsletter, Global Interests.

Ielpo, F. \& Sevi, B. (2013). Forecasting the density of oil futures returns using model-free implied volatility and highfrequency data. Montpellier, France: Centre de Recherche en Economie et Droit de l'Energie CREDEN Equipe ART Dev, Université Montpellier, Faculté d'Economie, Cahier de recherche n 13.10.106.

Ji, Q., Liu, B.Y., Zhao W.L. \& Fan, Y. (2018). Modelling dynamic dependence and risk spillover between all oil price shocks and stock market returns in the BRICS. $6^{\text {th }}$ International Symposium on Environment Energy \& Finance Issues, ISEFI 2018, Paris, France, May 24-25.

Kaabia, O., Dhaoui, A., Abid, I. \& Guesmi, K. (2018). Oil supply-demand shocks and stock prices. Retrieved from https://www.researchgate.net/publication/324687727_Oil_supply-demand_shocks_and_stock_prices

Kahneman, D. \& Tversky, A. (1979). Prospect theory: An analysis of decision under risk. Econometrica, 47, 2, $263-$ 291.

Kilian, L. \& Zhou, X. (2018). The propagation of regional shocks in housing markets: Evidence from oil price shocks in Canada. Centre for Economic Policy Research, London, UK, CEPR Discussion Paper DP12845. Retrieved from https://papers.ssrn.com/sol3/papers.cfm?abstract_id=3159148

Kirchler, E.M. (2007). The economic psychology of tax behaviour. Cambridge, UK: Cambridge University Press.

Klein, T., von Mettenheim, H.J., Walther, Th. \& Wegener, Ch. (2018). Forecasting high frequency realized volatility of oil with exogenous regressors. $6^{\text {th }}$ International Symposium on Environment Energy \& Finance Issues, ISEFI 2018, Paris, France, May 24-25.

Kruse, R. \& Wegener, Ch. (2017). Time-varying persistence in real oil prices and its determinants. Working paper retrieved from http://www.wisostat.uni-koeln.de/sites/statistik/abstracts/RKB-Time-

Varying_Persistence_in_Real_Oil_Prices_and_its_Determinant.pdf

Legnazzi, Ch. (2018). Forward-looking VaR and CVaR: An application to the natural gas market. $6^{\text {th }}$ International Symposium on Environment Energy \& Finance Issues, ISEFI 2018, Paris, France, May 24-25.

Leontief, W. (1997). Input-output economics. Oxford, UK: Oxford University Press.

Lips, J. (2018). Debt and the oil industry: Analysis on the firm and production level. Retrieved from https://papers.ssrn.com/sol3/papers.cfm?abstract_id=3026063

Mahadeo, S.M.R., Heinleinb, R. \& Legrenzib, G.D. (2018). New contagion applications for the energy-finance nexus: A higher moment approach. $6^{\text {th }}$ International Symposium on Environment Energy \& Finance Issues, ISEFI 2018, Paris, France, May 24-25.

Markowitz, E.M., Grasso, M. \& Jamieson, D. (2015). Climate ethics at a multidisciplinary crossroad: Four directions for future scholarship. Climate Change, 130, 3, 465-474.

Marron, D.B. \& Morris, A.C. (2016). How to use carbon tax revenues. Washington, D.C.: Tax Policy Center Urban Institute \& Brookings Institution.

Marx, K. (1867/1995). Capital: A critique of political economy. Moscow, RU: Progress.

Moore, J.W. (2009). Ecology and the accumulation of capital: A brief environmental history of neoliberalism. Paper presented at the Workshop on Food, Energy, Environment: Crisis in the Modern World-System. Fernand Braudel Center, Binghampton University, October 9-10.

Mumford, A. (2001). Taxing culture. Aldershot, UK: Ashgate.

Nordhaus, W.D. (1994). Mapping the global commons: The economics of climate change. Cambridge, MA: MIT Press.

Ordu-Akkaya, B.M. \& Soytas, U. (2018). The impact of foreign portfolio investment on financialization of commodities. $6^{\text {th }}$ International Symposium on Environment Energy \& Finance Issues, ISEFI 2018, Paris, France, May $24-25$

Orttung, R. (2010a). Politics and profits in Russia's foreign oil and gas conflicts. Center for Security Studies Colloquium, Swiss Federal Institute of Technology, August 30.

Orttung, R. (2010b). Five myths about energy security. Energy Forum 2010, Swiss Federal Institute of Technology, May 11. 
Orttung, R. (2014). Russia's place in the world energy system: Fueling the future: Deconstructing the role of energy in contemporary international relations. Toronto, Canada: University of Toronto, January 25.

Orttung, R. (2015). Promoting sustainability in Russia's artic: Integrating local, regional, federal, and corporate interest. In S. Oxenstierna (Ed.), The Challenges for Russia's Policized Economic System, pp. 202-219. London, UK: Routledge.

Orttung, R. (2016). Sustaining Russia's arctic cities: Resource politics, migration, and climate change. New York, NY: Berghahn.

Orttung, R. \& Overland, I. (2011a). A limited toolbox: Explaining the constraints on Russia's foreign energy policy. Journal of Eurasian Studies, 2, 1, 74-85.

Orttung, R. \& Overland, I. (2011b). Russia and the formation of a gas cartel. Problems of Post-Communism, 58, 3, 53-66.

Perovic, J., Orttung, R.W. \& Wenger, A. (2009). Russian energy power and foreign relations. London: Routledge.

Puaschunder, J. M. (2015). Trust and reciprocity drive common goods allocation norms. Proceedings of the Cambridge Business \& Economics Conference. Cambridge, UK: Cambridge University.

Puaschunder, J.M. (2016). Intergenerational climate change burden sharing: An economics of climate stability research agenda proposal. Global Journal of Management and Business Research: Economics and Commerce, 16, 3 , 31-38.

Puaschunder, J.M. (2017a). Climate in the 21 ${ }^{\text {st }}$ century: A macroeconomic model of fair global warming benefits distribution to grant climate justice around the world and over time. Proceedings of the 8th International RAIS Conference on Social Sciences and Humanities organized by Research Association for Interdisciplinary Studies (RAIS) at Georgetown University, Washington, D.C., United States, March 26-27, pp. 205-243.

Puaschunder, J. M. (2017b). Mapping Climate in the 21st Century. Development, 59, 3, 211-216.

Puaschunder, J.M. (2017c). Socio-psychological motives of socially responsible investors. Advances in Financial Economics, 19, 1, 209-247.

Puaschunder, J.M. (2017d). Sunny side up! From climate change burden sharing to fair global warming benefits distribution: Groundwork on the metaphysics of the gains of global warming and the climatorial imperative. Proceedings of the Administrative Sciences Association of Canada Annual Conference, HEC Montreal, Quebec, Canada.

Puaschunder, J.M. (2017e). The call for global responsible inter-generational leadership: The quest of an integration of inter-generational equity in corporate social responsibility (CSR) models. In Natural resources management: Concepts, methodologies, tools, and applications: Information resources management association. Hershey, PA: IGI Global.

Puaschunder, J.M. (2018a). Gifts without borders: Intergenerational glue connecting over distance and time as pure international development in the age of migration. In J. M. Puaschunder (Ed.), Intergenerational responsibility in the $21^{\text {st }}$ century, pp. 143-174. Wilmington, DE: Vernon.

Puaschunder, J.M. (2018b). Value at looking back: Towards an empirical validation oft he role of reflexibility in econo-historic backtesting: Economic market prediction corrections correlate with future market performance. Social Science Research Network Working Paper retrieved from https://papers.ssrn.com/sol3/papers.cfm?abstract_id=3170734

Puaschunder, J. M. (forthcoming a). Climate polices with burden sharing: The economies of climate financing. Advances in Financial Economics.

Puaschunder, J.M. (forthcoming b). Governance and climate justice: Global South and developing nations. Cham, Switzerland: Palgrave Macmillan.

Puaschunder, J.M. (forthcoming c). Nachhaltigkeit und Investment. In E. Bamberg \& C. Schmitt (Eds.), Psychologie und Nachhaltigkeit: Konzeptionelle Grundlagen, Anwendungsbeispiele und Zukunftsperspektiven. Hamburg, Germany: Springer.

Puaschunder, J.M. (work in progress). Climate change induced market prospects. Washington, DC: George Washington University working paper.

Renz, A. (2018). Sector competition for energy resources in a carbon constrained hoteling model. $6^{\text {th }}$ International Symposium on Environment Energy \& Finance Issues, ISEFI 2018, Paris, France, May 24-25. 
Puaschunder, J. M. (2019). An inquiry into the nature and causes of Climate Wealth of Nations: What temperature finance gravitates towards? Sketching a climate-finance nexus and outlook on climate change-induced finance prospects. Archives of Business Research, 7(3), $183-217$.

Ricardo, D. (1817/1951). On the principles of political economy and taxation. In P. Sraffa (Ed.), The Works and Correspondence of David Ricardo, pp. 1951-1973. Cambridge, UK: Cambridge University Press.

Roberts, G., Barbier, E. \& van't Veld, K.V. (2018). The beginning of the end of the age of oil. Retrieved from https://cenrep.ncsu.edu/cenrep/wp-content/uploads/2016/08/Roberts.pdf

Rosenlund Soysal, E. (2018). Share repurchase under diverging beliefs about carbon risk. $6^{\text {th }}$ International Symposium on Environment Energy \& Finance Issues, ISEFI 2018, Paris, France, May 24-25.

Sachs, J.D. (2014). Climate change and intergenerational well-being. In L. Bernard \& W. Semmler (Eds.), The Oxford Handbook of the Macroeconomics of Global Warming, pp. 248-259. Oxford, UK: Oxford University Press.

Saussay, A. \& Sato, M. (2018). The impacts of energy prices on industrial foreign investment location: Evidence from global firm level data. Retrieved from https://personal.lse.ac.uk/satom/publication/currentss/

Schmölders, G. (1960). Das Irrationale in der öffentlichen Finanzwirtschaft. Frankfurt am Main, Germany: Suhrkamp.

Schütze, F., Aleksovski, D. \& Mozetic, I. (2018). Stock market reactions to international climate negotiations. Retrieved from https://bibbase.org/network/publication/schtze-aleksovski-mozetistockmarketreactionstointernationalclimatenegotiations-2018

Schweiger, H. \& Stepanov, A. (2018). Energy subsidies, energy intensity and management practices. Retrieved from https://www.ebrd.com/cs/Satellite?c=Content\&cid=1395236502077\&d=Mobile\&pagename=EBRD\%2FContent \%2FContentLayout

Sherman, H.J. (1967). Marx and the business cycle. Science \& Society, 31, 4, 486-504.

Somanathan, E., Somanathan, R., Sudarshan, A. \& Tewari, M. (2014). The impact of temperature on productivity and labor supply: Evidence from Indian manufacturing. Discussion Paper in Economics 14-10, Indian Statistical Institute, Economics and Planning Unit.

Soros, G. (2003). The alchemy of finance. Hoboken, NJ: Wiley Finance.

Soros, G. (2009). The crash of 2008 and with is means. New York, NY: Public Affairs.

Soros, G. (2013). Fallibility, reflexivity and the human uncertainty principle. Journal of Economic Methodology, 20, 309-329.

Soskice, D. (1978) Strike waves and wage explosions, 1968-1970: An economic interpretation, In C.Crouch \& A. Pizzorno (Eds.), The Resurgence of Class Conflict in Western Europe since 1968, pp. 221-245, London, UK: Palgrave Macmillan.

Sraffa, P. (1960). Production of commodities by means of commodities. Cambridge, UK: Cambridge University Press.

Stiglitz, J. (1998). The private uses of public interests: Incentives and institutions. Journal of Economic Perspectives, 12, 3-22.

Stroebe, W. \& Frey, B.S. (1982). Self-interest and collective action: The economics and psychology of public goods. British Journal of Social Psychology, 21, 2, 121-137.

Täuber, S., van Zomeren, M. \& Kutlaca, M. (2015). Should the moral core of climate issues be emphasized or downplayed in public discourse? Three ways to successfully manage the double-edged sword of moral communication. Climate Change, 130, 3, 453-464.

The World Bank (2015). Green bonds attract private sector climate finance. World Bank Brief, 2015.

The World Economic Forum 2015 Report. (2015). Davos, Switzerland: World Economic Forum.

Trinks, A., Mulder, M. \& Scholtens, B. (2017). Greenhouse gas emissions intensity and the cost of capital. Retrieved from https://pdfs.semanticscholar.org/c8f5/d6b192df64cde5f578f100d7fb2a6b40515b.pdf

Tversky, A. \& Shafir, E. (1992). Choice under conflict: The dynamics of deferred decision. Psychological Science, 3 , 6, 358-361.

Tyler, T.R. \& De Cremer, D. (2006). How do we promote cooperation in groups, organizations, and societies? In P.A.M van Lange (Ed.), Bridging Social Psychology: Benefits of Transdisciplinary Approaches, pp. 427-433. Mahwah, NJ: Lawrence Earlbaum.

United Nations Report on the World Social Situation (2011). The global social crisis. New York, NY: United Nations Department of Economic and Social Affairs Report ST/ESA/334. 
Wenger, A., Orttung, R.W. \& Perovic, J. (2009). Energy and the transformation of international relations: Toward a new producer-consumer framework. Oxford, UK: Oxford University Press.

World Bank Group Migration and Development Brief 26 (2016). Migration and remittances: Recent development and outlook. Washington D.C.: International Bank for Reconstruction and Development, World Bank Group, April 2016.

World Bank 2015 Report. (2015). Washington, D.C.: World Bank.

World Investment Report (2015). Reforming international investment governance. United Nations Conference on Trade and Development Report. New York, NY: United Nations.

Yarlik, M.V., Filis, G., Lloyd, T. \& Degiannakis, St. (2018). Forecasting oil price volatility: The role of mixedfrequency data (MIDAS) model. $6^{\text {th }}$ International Symposium on Environment Energy \& Finance IsSues, ISEFI 2018, Paris, France, May 24-25.

Zhang, D. (2018). Upgrading China's energy structure: The role of financial markets. $6^{\text {th }}$ International Symposium on Environment Energy \& Finance Issues, ISEFI 2018, Paris, France, May 24-25.

Zhou, S.L., Smulders, S. \& Gerlagh, R. (2018). Closing the loop in a circular economy: Saving resources or suffocating innovations? $6^{\text {th }}$ International Symposium on Environment Energy \& Finance Issues, ISEFI 2018, Paris, France, May 24-25. 